Chapter 10

\title{
Development of a Stress Insensitive MgCuZn-NiCuZn Composite Ferrite Useful for Microinductors Applications
}

\author{
N. Varalaxmi and K. Sivakumar \\ Additional information is available at the end of the chapter \\ http://dx.doi.org/10.5772/52857
}

\section{Introduction}

Ferrite materials are recognized as more important and essential for the further development of electronics than before, and it is believed that the production of ferrites will increase year by year as their applications become more diverse.

A tendency to miniaturize electronic components began in the 1990s. Concurrently, progress also occurred in surface-mounting technology, and attempts have been made to accomplish high density, incorporation of ferrite inductors into a printed circuit board. This has, as a result, allowed development of various types of multilayer ferrite chip inductors [1]. Generally, this has a length of $10 \mathrm{~mm}$ and a width of $0.5 \mathrm{~mm}$, to be used in television receivers, video equipment, headphone stereos, hard disk device systems, personal computers, cordless telephones, automobiles parts etc. Multilayer ferrite chip inductors are manufactured using the thick film printing method, and the latest chip inductors are successfully constructed as a single monolithic structure that combines the inductor with other passive elements such as capacitors and resistors.

The present chip inductor features make the miniaturization process very easy. The flux is entirely free from leakage because the coil is shielded with ferrite material. Hence it is expected that the demand for the chip inductors will increase in future.

Chip inductors are one of the passive surface mounting devices (SMD). They are important components for the latest electronic products such as cellular phones, video cameras, note book computers, hard and floppy drives etc., and those that require small dimensions, light weight and better functions [2-3]. The traditional wire wound chip inductors can only be miniaturized to a certain limit and lack of magnetic shielding leads to the development of 
new materials for the multilayer chip inductors. In this direction only NiCuZn ferrites were developed as the core material used in the chip inductors [4-5]. But, it was found that these ferrites are comparatively sensitive to stress and magnetic properties are easily changed or deteriorated by the stress caused at the electrode.

Silver is generally used as the material for the internal electrode of the multilayer chip inductors due to its low resistivity, resulting in the components with high quality factor $(Q)$ [4]. In addition to this, $\mathrm{Ag}$ paste is commercially available at lower cost than Ag-Pd paste. Since the melting point of silver is $961^{\circ} \mathrm{C}$, the sintering temperature of ferrite which is used for the manufacture of chip inductor should be below $950{ }^{\circ} \mathrm{C}$. This is because of the need to prevent Ag diffusion into the ferrite that would increase the resistivity of the internal conductor. Further, the segregation of $\mathrm{Cu}^{2+}$ from the ferrite induced by the diffused $\mathrm{Ag}$ can be avoided and thus no deterioration in magnetic properties of the material. In order to overcome these problems, $\mathrm{MgCuZn}$ ferrites were found to be suitable [6-8]. Normally, $\mathrm{MgCuZn}$ ferrites were sintered at temperatures higher than $1100{ }^{\circ} \mathrm{C}[6-7,9]$. In order to use these ferrites in multilayer chip components the sintering temperature must not be more than the melting point of silver.

With the rapid development and advancement of mobile communication and information technology, the electronic components with small size, high efficiency and low cost are urgently needed [10]. Multilayer chip inductors (MLCI) as key component of electronic devices confront new challenges. Better magnetic properties, especially high initial permeability are required for reducing the number layers of multi layer chip inductors. At present $\mathrm{Ni}$ $\mathrm{CuZn}$ ferrites have been used extensively for the production of the MLCI [11]. But NiCuZn ferrites are highly stress sensitive. The $\mathrm{MgCuZn}$ ferrite is also a pertinent magnetic material for wide range of applications owing to its high resistivity, fairly high Curie temperature, low magnetostriction, environmental stability and low cost [6-16].

In search of suitable ferrite materials for microinductor applications, an attempt has been made, in the present work, to prepare ferrite composites containing two pure ferrite components viz., $\mathrm{NiCuZn}$ and $\mathrm{MgCuZn}$ ferrites with high initial permeability viz., $1-\mathrm{x}$ $\left(\mathrm{Mg}_{0.25} \mathrm{Cu}_{0.25} \mathrm{Zn}_{0.5} \mathrm{Fe}_{2} \mathrm{O}_{4}\right)+x\left(\mathrm{Ni}_{0.35} \mathrm{Cu}_{0.05} \mathrm{Zn}_{0.6} \mathrm{Fe}_{2} \mathrm{O}_{4}\right.$ ), (where $x$ varies as $0.0,0.2,0.4,0.5,0.6,0.8$ and 1.0) with a view to examine whether there would be any enhancement of magnetic properties in this system. In this system both the end members have fairly high permeability. This attempted is made to reduce the stress sensitivity of the ferrites since the magnetostriction constant of $\mathrm{MgCuZn}$ ferrite is lower than that of NiCuZn ferrite [11]. It was also expected that MLCI using MgCuZn ferrites would show better magnetic properties [7] comparable to that of NiCuZn ferrites and can realize low cost MLCIs with MgCuZn ferrites. Therefore in the present investigation along with the $\mathrm{MgCuZn}$ and $\mathrm{NiCuZn}$ ferrites as pure components and their composites were chosen. Since, the author has been studying the modification of soft magnetic ferrites, for different applications, she thought that, the ferrites composites would produce dense microstructure and excellent magnetic properties. To the best of the author's knowledge no systematic investigation on the composites containing (NiCuZn-MgCuZn ferrites) were made, hence the author has under taken a detailed study of initial permeability in these composites. 
In this paper, different mole fractions of the ferrites composites with generic formula 1-x $\left(\mathrm{Mg}_{0.25} \mathrm{Cu}_{0.25} \mathrm{Zn}_{0.5} \mathrm{Fe}_{2} \mathrm{O}_{4}\right)+x\left(\mathrm{Ni}_{0.35} \mathrm{Cu}_{0.05} \mathrm{Zn}_{0.6} \mathrm{Fe}_{2} \mathrm{O}_{4}\right)$ where ' $\mathrm{x}$ ' varies from 0.0 to 1.0 were prepared and an attempt was made both to promote the high initial permeability ferrite composites and having stress insensitivity.

\section{Experimental}

\subsection{Preparation of ferrite composites}

Ferrite composites with ferrimagnetic phases have been prepared by employing conventional ceramic method.

In the present investigation the ferrite composites contain two ferrite components viz.,

i. $\quad \mathrm{Mg}_{0.25} \mathrm{Cu}_{0.25} \mathrm{Zn}_{0.5} \mathrm{Fe}_{2} \mathrm{O}_{4}(\mathrm{MgCuZn}$ ferrite)

ii. $\quad \mathrm{Ni}_{0.35} \mathrm{Cu}_{0.05} \mathrm{Zn}_{0.6} \mathrm{Fe}_{2} \mathrm{O}_{4}$ (NiCuZn ferrite)

The pure components, viz., $\mathrm{Mg}_{0.25} \mathrm{Cu}_{0.25} \mathrm{Zn}_{0.5} \mathrm{Fe}_{2} \mathrm{O}_{4}$ and $\mathrm{Ni}_{0.35} \mathrm{Cu}_{0.05} \mathrm{Zn}_{0.6} \mathrm{Fe}_{2} \mathrm{O}_{4}$ compositions were prepared using the conventional ceramic double sintering method.

First, the composition $\mathrm{Mg}_{0.25} \mathrm{Cu}_{0.25} \mathrm{Zn}_{0.5} \mathrm{Fe}_{2} \mathrm{O}_{4}$ was prepared by employing conventional ceramic double sintering method using analytical grade $\mathrm{MgO}, \mathrm{CuO}, \mathrm{ZnO}$ and $\mathrm{Fe}_{2} \mathrm{O}_{3}$ in their respective proportions. These oxides were weighed and intimately mixed and then ball-milled with acetone using polyethylene jars and iron balls $(\phi=5 \mathrm{~mm})$ media for 24 hrs. The ground powders were presintered at $800{ }^{\circ} \mathrm{C}$ in the form of cakes. After pre-sintering, these cakes were crushed, ground again to obtain fine particle size and finally these powders were sieved to get uniform particle size. The $\mathrm{Ni}_{0.35} \mathrm{Cu}_{0.05} \mathrm{Zn}_{0.6} \mathrm{Fe}_{2} \mathrm{O}_{4}$ composition was also prepared in the same method by employing conventional ceramic double sintering method using analytical grade $\mathrm{NiO}, \mathrm{CuO}, \mathrm{ZnO}$ and $\mathrm{Fe}_{2} \mathrm{O}_{3}$ in their respective proportions.

The ferrite composites were prepared by mixing the two individual green powders in molar proportions 1-x $\left(\mathrm{Mg}_{0.25} \mathrm{Cu}_{0.25} \mathrm{Zn}_{0.5} \mathrm{Fe}_{2} \mathrm{O}_{4}\right)+x\left(\mathrm{Ni}_{0.35} \mathrm{Cu}_{0.05} \mathrm{Zn}_{0.6} \mathrm{Fe}_{2} \mathrm{O}_{4}\right)$ in which ' $\mathrm{x}$ ' varies from $0.0,0.2,0.4,0.5,0.6,0.8$ and 1.0. These compositions were taken in the respective proportions as mentioned above and they were ultimately mixed and ground further to obtain fine powder.

These presintered powders were mixed with $2 \%$ PVA as a binder and were compacted in the form of toroids of $12 \mathrm{~mm}$ outer diameter; $8 \mathrm{~mm}$ inner diameter; and $4 \mathrm{~mm}$ height to measure the initial permeabilities and their Curie temperature, and in the form of cylinders of diameter $10 \mathrm{~mm}$ and length nearly $20 \mathrm{~mm}$ to study the effect of external stress, using hydraulic press by applying a pressure of $150 \mathrm{MPa}$. These compacted bodies were finally sintered at $1250{ }^{\circ} \mathrm{C}$ for $2 \mathrm{hrs}$ in a programmable furnace and were cooled to room temperature at the rate of $80^{\circ} / \mathrm{hr}$. Sufficient care was taken to avoid the zinc loss during the sintering process. 
All the samples were structurally characterized by X-ray powder diffraction analysis using a Philips diffractometer $\mathrm{PW}-1710$ with monochromatised $\mathrm{CuK}_{\alpha}$ radiation at room temperature. Infrared spectra of pure components and the equimolar composition were recorded using Perkin-Elmer FT-IS spectrometer Model 1605 in the wave number range $400-1100 \mathrm{~cm}^{-1}$ at room temperature. The scanning electron micrographs of samples were obtained using (Philips XL30ESEM) instrument. The samples were laped and polished using $0.3 \mu \mathrm{m}$ alumina powder and later they were thermally etched. The thermally etched and gold coated samples were used for obtaining the SEM photographs.

\subsubsection{Analysis of X-ray diffractograms of ferrite composite system}

1-x $\left(\mathrm{Mg}_{0.25} \mathrm{Cu}_{0.25} \mathrm{Zn}_{0.5} \mathrm{Fe}_{2} \mathrm{O}_{4}\right)+x\left(\mathrm{Ni}_{0.35} \mathrm{Cu}_{0.05} \mathrm{Zn}_{0.6} \mathrm{Fe}_{2} \mathrm{O}_{4}\right)$

Typical X-ray patterns obtained in the present investigation for ferrimagnetic composites with generic formula 1-x $\left(\mathrm{Mg}_{0.25} \mathrm{Cu}_{0.25} \mathrm{Zn}_{0.5} \mathrm{Fe}_{2} \mathrm{O}_{4}\right)+x\left(\mathrm{Ni}_{0.35} \mathrm{Cu}_{0.05} \mathrm{Zn}_{0.6} \mathrm{Fe}_{2} \mathrm{O}_{4}\right)$ where $\mathrm{x}=1.0,0.5$ and 0.0 are presented in Figs $1 \mathrm{a}, 1 \mathrm{~b}$ and $1 \mathrm{c}$ respectively. An examination of the x-ray diffractograms reveals that both pure ferrites and composite show the formation of single phase cubic spinel structure showing well-defined peaks.

\subsubsection{Scanning electron micrographs}

Typical microstructures of the pure components and a few composites are obtained using SEM. The scanning electron micrographs of pure components and equimolar mixture along with $x=0.4$ were taken with the help of Philips XL30ESEM. Thermally etched samples were taken for making the SEM specimens. The samples were mounted on brass studs with double sided adhesive tape and coated with Au-Pd alloy of 120-150 A ${ }^{\circ}$ thickness in argon ambient atmosphere of 8-10 Pascal. Then the samples were scanned for various surfaces and the best photographs were recorded. These photographs are shown in Figs.2a, 2b and 2c. An examination of the figures presented shows clearly the uniform distribution of the ferrite phases.

\subsubsection{Infrared analysis}

The infrared spectra of $\mathrm{MgCuZn}$ and $\mathrm{NiCuZn}$ ferrites and their equimolar mixture are shown in Figs.3a, 3b and 3c All the samples show only two absorption bands, viz., high frequency band $v_{1}$ and second absorption band $v_{2}$ which are found to be in the range 571 to $563 \mathrm{~cm}^{-1}$ and 400 to $398 \mathrm{~cm}^{-1}$ respectively. The difference is expected because of the difference in $\mathrm{Fe}^{3+}-\mathrm{O}^{2-}$ distance of the octahedral and tetrahedral sites. The $v_{1}$ band is assigned to the tetrahedral co-ordination, $v_{2}$ and $v_{3}$ to octahedral co-ordination compounds where as $v_{4}$ is attributed to some sort of lattice vibrations involving displacement of tetrahedral cations [17]. It is reported that the systems in more disorder state gives rise to broader and less intense bands in IR spectra [18]. 


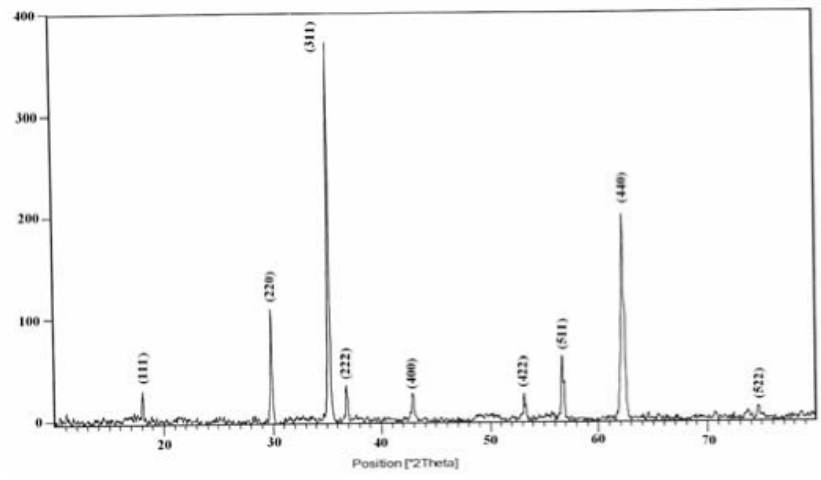

(a)

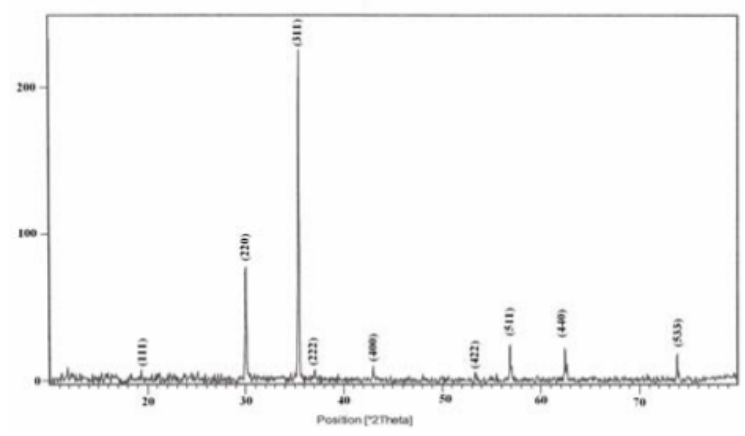

(b)

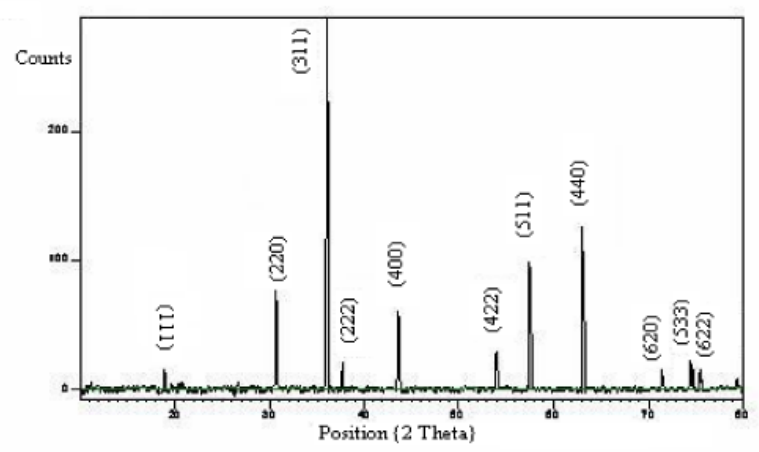

(c)

Figure 1. X-ray diffractograms of pure components and ferrite composite (a) $X=0.0$, (b) $X=0.5$ and (c) $X=1.0$. 


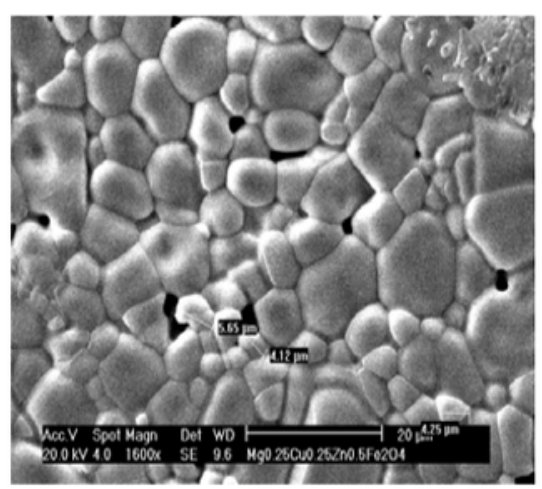

(a) $\mathrm{X}=0.0$

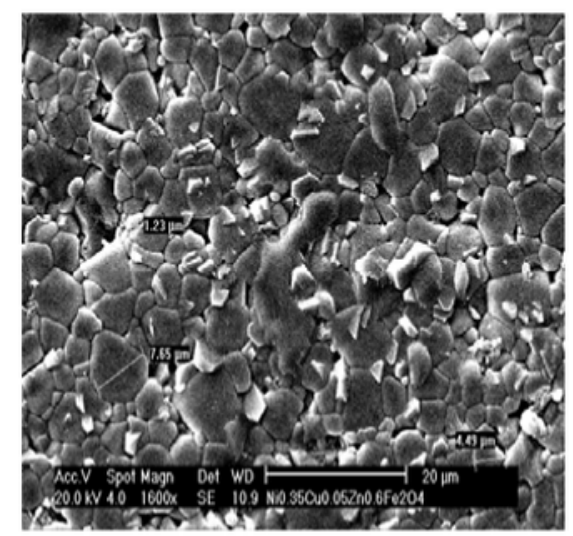

(b) $\mathrm{X}=1.0$

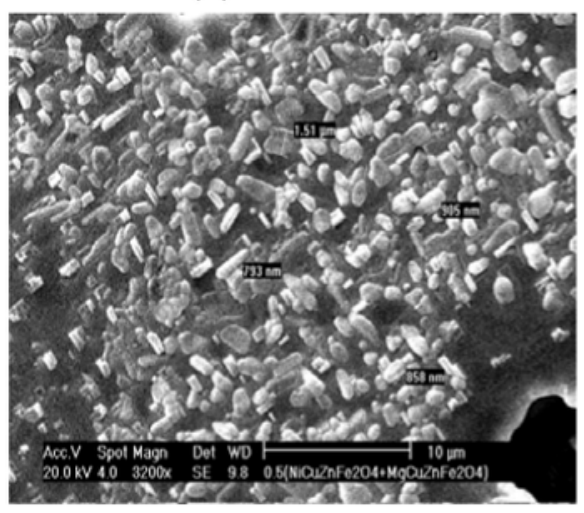

(c) $\mathrm{X}=0.5$.

Figure 2. SEM photographs of ferrites composites (a) $X=0.0$, (b) $X=1.0$ and (c) $X=1.0$. 


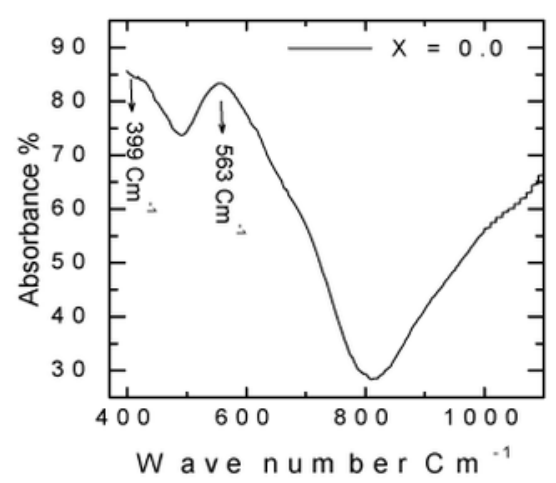

(a)

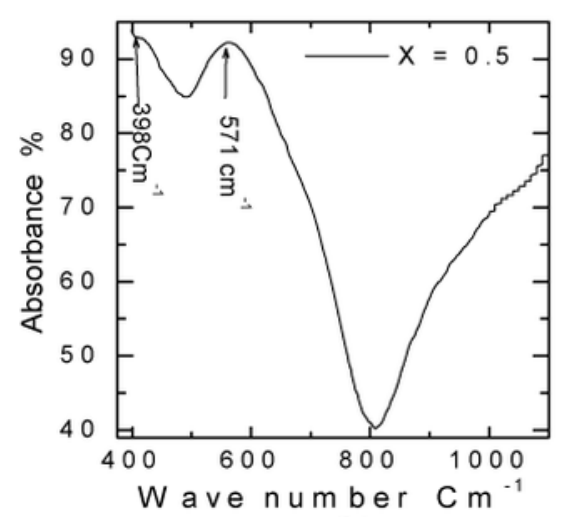

(b)

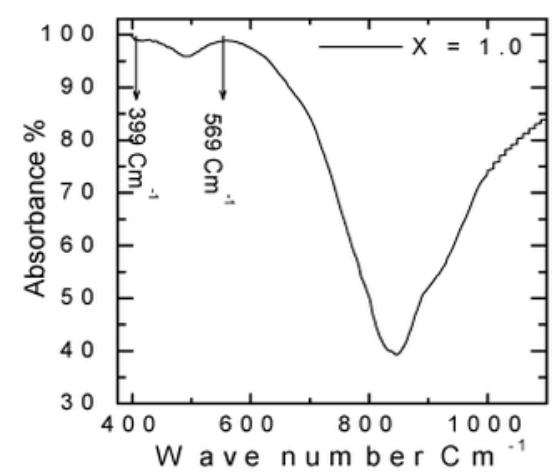

(c)

Figure 3. Infrared spectra of ferrite composites (a) $X=0.0$, (b) $X=0.5$ and (c) $X=1.0$. 


\section{Experimental technique}

a. Initial permeability

For the determination of the initial permeability $\left(\mu_{i}\right)$ the samples were prepared in the form of toroids with the help of suitable die having an inner diameter of $8 \mathrm{~mm}$ outer diameter of $12 \mathrm{~mm}$ and $4 \mathrm{~mm}$ height and 30 to 35 turns of insulated copper wire (24SWG) was wound on the toroid and was used as a test specimen. The initial permeability, $\mu_{\mathrm{i},}$ of these ferrite toroids were evaluated using the standard formulae from the inductance measurements carried out at $1 \mathrm{kHz}$ using impedance analyzer (Hioki Model 3532-50 LCR HiTester). The values of inductance were recorded noted in the temperature range $25{ }^{\circ} \mathrm{C}$ to $250{ }^{\circ} \mathrm{C}$ in the frequency of $500 \mathrm{~Hz}$ to $1000 \mathrm{kHz}$. The permeability was calculated by using the relation

$$
L=0.0046 N^{2} * \mu_{i}^{*} h^{*} \log _{10}\left(\frac{D_{1}}{D_{2}}\right)
$$

Where $L$ is the inductance in micro henrys, $h$ is the height of the core in inches, $D_{1}$ and $D_{2}$ are the outer and inner diameters in inches $\mu_{\mathrm{i}}$ is the permeability of the core and $\mathrm{N}$ is the number of turns.

\section{b. Stress sensitivity}

In order to study the effect of external stress, uniaxial compressive stress parallel to the magnetizing direction was applied to the cylindrical shape ferrite cores using uniaxial press system. The stress magnitudes were varied from 0 to $10 \mathrm{MPa}$. The change in inductance was measured using the above mentioned LCR HiTester by employing 120 turns coil wound on each cylinder.

\section{c. Excess permeability and excess volume}

From the experimental measurements of molar volume (molecular weight/density) and initial permeability the excess parameters $\mathrm{V}^{\mathrm{E}}$ and $\mu_{\mathrm{i}}^{\mathrm{E}}$ are evaluated using the formulae

$$
\mathrm{V}^{\mathrm{E}}=\mathrm{V}_{\exp }-\left[\mathrm{V}_{1}(1-\mathrm{x})+\mathrm{V}_{2} \mathrm{x}\right]
$$

and

$$
\mathrm{m}_{\mathrm{i}}^{\mathrm{E}}=\mathrm{m}_{\mathrm{iexp}}-\left[\mathrm{m}_{\mathrm{i} 1}(1-\mathrm{x})+\mathrm{m}_{\mathrm{i} 2} \mathrm{x}\right]
$$

where $\mathrm{V}^{\mathrm{E}}$ and $\mu_{\mathrm{i}}^{\mathrm{E}}$ are excess molar volume and excess initial permeability. The quantities in the brackets are the ideal values. The excess parameters obtained in the present work are presented as function of mole fraction $x$ in Fig. 5 at room temperature. 


\section{A brief review of initial permeability work carried out on $\mathrm{MgCuZn}$ and NiCuZn ferrites}

Development of nickel copper zinc ferrites for use in high performance multilayer chip ferrites were investigated by Suzuki et.al., [19]. Kanada et.al., [20] studied the replacement of $\mathrm{Fe}_{2} \mathrm{O}_{3}$ by $\mathrm{Mn}_{2} \mathrm{O}_{3}$ and replacement of $\mathrm{CuO}$ for $\mathrm{MgO}$ in $\mathrm{MgZn}$ ferrite in order to achieve low core loss, focusing on the microstructure. They have also investigated the initial permeability of MnZn, MnMgZn and MnMgCuZn ferrites and concluded that the initial permeability of both MnMgZn and MnMgCuZn ferrites are higher than those of MgZn ferrite.

Yan et.al., [21] studied the effect of $\mathrm{CuO}$ and $\mathrm{V}_{2} \mathrm{O}_{5}$ additions and the particle size of precursor materials on the microstructure and relative initial permeability of low temperature fired $\mathrm{NiCuZn}$ ferrites and found that the additions of $\mathrm{CuO}$ and $\mathrm{V}_{2} \mathrm{O}_{5}$ contribute to the grain growth and densification of matrix in the sintering process. Addition of $10 \mathrm{~mol} \% \mathrm{CuO}$ and $0.20 \mathrm{~mol} \% \mathrm{~V}_{2} \mathrm{O}_{5}$, favoured the low firing temperature of $\mathrm{NiCuZn}$ ferrite, and showed very high relative initial permeability of 1417 at $1 \mathrm{MHz}$. Zhang et.al., [11] carried out the preparation of $\left(\mathrm{Ni}_{0.15} \mathrm{Cu}_{0.25} \mathrm{Zn}_{0.60}\right) \mathrm{Fe}_{1.96} \mathrm{O}_{4}$ ferrite with very high initial permeability from self-propagated powders. Caultun et.al., [22] studied the magnetic properties of high frequency Ni- $\mathrm{Zn}$ ferrites doped with CuO. Nakamura et.al., [23] studied the frequency dispersion of permeability in ferrite composite materials and observed that permeability spectra of Ni-Zn ferrite composite materials. They observed that in the sintered ferrite (volume fraction 1.0), the spin resonance was around $9 \mathrm{MHz}$ and the static permeability was about 1400 . As the ferrite content decreases in composite materials, the static susceptibility of the spin component decreases and the spin resonance frequency shifts to higher frequencies. The real part of the permeability in the ferrite composite materials becomes larger than that of the sintered ferrite in the rf frequency region.

Oh [24] studied the effect of $\mathrm{MnO}$ addition on sintering behaviour and magnetic properties of NiCuZn ferrites for multilayer chip inductors. Su et.al., [25] studied the effect of composition and sintering temperature on grain size, porosity and magnetic properties of the NiZn and NiCuZn ferrites. It was found that the lowest power loss could be obtained with the equimolar composition for both $\mathrm{NiZn}$ and $\mathrm{NiCuZn}$ ferrites, which could be attributed to the lowest porosity.

High strength NiCuZn ferrite used for surface mounting devices was investigated by Murayama et.al., [26]. Kanada et.al., [27] studied the effects of chemical composition and microstructure on the stress sensitivity of initial permeability of $\mathrm{NiMgCuZn}$ ferrites. When the external stress is applied to the ferrites, the reduction of initial permeability due to the deficiency of $\mathrm{Fe}_{2} \mathrm{O}_{3}$ was observed. Furthermore, they reported that a finely dispersed grain size in microcrystalline structure is highly effective in stabilization of initial permeability. As the compressive stress is applied parallel to the magnetic field, the maximum initial permeability of NiCuZn ferrite could be observed at $4 \mathrm{MPa}$. On the other hand, in the case of $\mathrm{MgCuZn}$ ferrite the maximum was observed at around $0 \mathrm{MPa}$. It seems possible to stabilize the initial permeability against the external stress by adjusting composition ratio of $\mathrm{NiO} /(\mathrm{NiO}+\mathrm{MgO})$. 
Bhosale et.al., [28] presented a novel route for the preparation of high density, high permeability $\mathrm{Cu}-\mathrm{Mg}-\mathrm{Zn}$ ferrites using oxalate precursor method, with various $\mathrm{Mg}^{2+}$ contents with a generic formula $\mathrm{Cu}_{(0.5-x)} \mathrm{Mg}_{\mathrm{x}} \mathrm{Zn}_{0.5} \mathrm{Fe}_{2} \mathrm{O}_{4}$ where $\mathrm{x}=0.00,0.20,0.25$ and 0.40. They investigated the ferritization temperature of this system and observed the initial permeability of all the samples increased with increase in sintering temperature and $\mathrm{Mg}^{2+}$ content for samples with $x \leq 0.20$.

Yan and $\mathrm{Hu}$ [29] studied the $\left(\mathrm{Ni}_{0.20} \mathrm{Zn}_{0.60} \mathrm{Cu}_{0.20}\right) \mathrm{Fe}_{1.98} \mathrm{O}_{4}$ ferrite which was sintered using microwave sintering and conventional sintering techniques, respectively and found that microwave sintering technique could effectively promote the forward diffusion of ions and thus accelerate the sintering process, resulting in the grain growth and the densification of the matrix. They found that at $100 \mathrm{kHz}$, the magnetizing contribution of domain wall motion is predominant. Compact and coarse matrices are favorable for domain wall motion, giving rise to improvement of relative initial permeability and loss of ferrites. With microwave sintering technique, $\left(\mathrm{Ni}_{0.20} \mathrm{Zn}_{0.60} \mathrm{Cu}_{0.20}\right) \mathrm{Fe}_{1.98} \mathrm{O}_{4}$ ferrite with the relative initial permeability $\mu_{\mathrm{i}}$ of about 2000 and the relative loss factor tan $\delta / \mu_{\mathrm{i}}$ of about $8.7 \times 10^{-6}$ at $100 \mathrm{kHz}$ were achieved at $980{ }^{\circ} \mathrm{C}$ sintering temperature. In addition, the sintering time of ferrites was reduced from 5 to $0.5 \mathrm{~h}$ by using microwave sintering technique.

Ghodake et.al., [30] studied the magnetic properties of NiCuZn ferrites with generic formula $\mathrm{Ni}_{\mathrm{x}} \mathrm{Cu}_{[(1-\mathrm{t})-\mathrm{x}]} \mathrm{Zn}_{\mathrm{t}} \mathrm{Fe}_{2}\left(\mathrm{C}_{2} \mathrm{O}_{4}\right) \cdot \mathrm{n} \cdot \mathrm{H}_{2} \mathrm{O}$ where $\mathrm{t}=0.45,0.50,0.60$ and $\mathrm{x}=0.0,0.05,0.10,0.15$, $0.20,0.30,0.40,0.50$ and 0.55 were synthesized by oxalate precursor method and observed that the initial permeability $\left(\mu_{\mathrm{i}}\right)$ showed an increase when $\mathrm{Ni}^{2+}$ was added up to $\mathrm{x}=0.15$ while for $x>0.15$, it decreased. The increase in initial permeability $\left(\mu_{\mathrm{i}}\right)$ was attributed by them to monotonic increase in $\mathrm{M}_{\mathrm{s}}$ and $\mathrm{K}_{1}$ on addition of $\mathrm{Ni}^{2+}$. However, the microstructure and density (porosity) also influence $\mu_{\mathrm{i}}$ variations. The decrease in $\mu_{\mathrm{i}}$ is attributable to increase of $K_{1}$.

Xiao et.al., [31] studied the fabrication of solenoid type inductor with electro pated NiFe magnetic core, the inductance and quality factor were $0.42-0.345 \mu \mathrm{H}$ and $1.8-5.3$ in the frequency range 1-10 $\mathrm{MHz}$ respectively. Bhosale et.al., [32] studied a novel route for the preparation of high density, high permeability $\mathrm{Cu}-\mathrm{Mg}-\mathrm{Zn}$ using oxalate precursor method for various $\mathrm{Mg}^{2+}$ contents with generic formula $\mathrm{Cu}_{(0.5-\mathrm{x})} \mathrm{Mg}_{\mathrm{x}} \mathrm{Zn}_{0.5} \quad \mathrm{Fe}_{2} \mathrm{O}_{4}$ where $\mathrm{x}=0.0,0.2,0.25$ and 0.4 have been carried out in the temperature range 599 to $743 \mathrm{~K}$ and observed that initial permeability of all the samples increases with increase in temperature and $\mathrm{Mg}^{2+}$ content upto $\mathrm{x} \leq 0.2$.

Densification and magnetic properties of low-temperature fired NiCuZn ferrites was studied by Wang et.al., [33]. Effects of presintering temperature on the property of high permeability of NiCuZn ferrite was studied by Su et.al., [34]. Mukesh et.al., [35] prepared fine powders of $\mathrm{Ni}_{0.6-\mathrm{x}} \mathrm{Cu}_{\mathrm{x}} \mathrm{Zn}_{0.4} \mathrm{Fe}_{2} \mathrm{O}_{4}$ where $0 \leq \mathrm{x} \leq 0.4$ by citrate precursor method under investigation and they concluded that the ferrite with $\mathrm{Cu}$ concentration of $\mathrm{x}=0.4$ showed highest initial permeability. Enhancement initial permeability of low temperature sintered $\mathrm{NiCuZn}$ ferrites was investigated by Oi et.al., [36]. The study of low temperature sintered $\mathrm{MgCuZn}$ ferrites were carried out by Nakahata et.al., [37]. 
Ramamanohar Reddy et.al., [38] studied the stress sensitivity of inductance in NiCuZn ferrites and the initial permeability measurements were reported in the temperature range 30-400 ${ }^{\circ} \mathrm{C}$. Nam et.al., [39] studied the effect of $\mathrm{Cu}$ substitution on the properties of NiZn ferrites sintered at low temperature in various compositions, they concluded that the densification of NiCuZn ferrite is dependent on $\mathrm{Cu}$ content in these ferrites, Dispersion characteristics of complex permeability in $\left(\mathrm{Ni}_{0.5-\mathrm{x}} \mathrm{Cu}_{\mathrm{x}} \mathrm{Zn}_{0.5}\right)\left(\mathrm{Fe}_{2} \mathrm{O}_{3}\right)_{0.98}$ was reported by them and They also showed that the relaxation frequency increases with increasing temperature. Caultn [40] studied the dependence of permeability spectra on the frequency for samples of $\mathrm{Ni}-\mathrm{Zn}-\mathrm{Cu}$ ferrite sintered at different temperatures. The effect of $\mathrm{Cu}$ substitution on the properties of magnesium zinc ferrites sintered at low temperature were investigated by Rezlescu et.al., [14]. Densification and properties of flux added NiCuZn ferrites were carried out by Wang et.al., [41].

Wang et.al., [42] also studied the densification and magnetic properties of low temperature fired NiCuZn ferrites. Murthy [43] studied the electrical and magnetic properties of low temperature sintered $\mathrm{MgCuZn}$ ferrites. Wang et.al., [44] also studied the effects of processing on the densification and properties of low-temperature fired NiCuZn ferrites. Bhosale et.al., [45] studied the synthesis of high permeability $\mathrm{Cu}-\mathrm{Mg}-\mathrm{Zn}$ ferrites using oxalate precursor method and concluded that for the sample with $\mathrm{x}=0.25$ in $\mathrm{Mg}_{\mathrm{x}} \mathrm{Cu}_{0.5-\mathrm{x}} \mathrm{Zn}_{0.5} \mathrm{Fe}_{2} \mathrm{O}_{4}$ has the highest permeability of $\left(\mu_{\mathrm{i}}=2158\right)$ which was sufficiently higher than that reported for ETMG-5 ferrite $\left(\mu_{\mathrm{i}}=550\right)$. Magnetic and structural properties of ultra fine $\mathrm{Ni}-\mathrm{Zn}-\mathrm{Cu}$ ferrite prepared by a sol-gel method were studied by Lee et.al., [46].

Effects of composition and sintering temperature on grain size, porosity and magnetic properties of the NiZn and NiCuZn ferrites were investigated by Hua Su et.al., [47] and they found that the lowest power loss could be obtained with the equimolar composition for both NiZn and NiCuZn ferrites, which could be attributed to the lowest porosity and a slight deficiency or excess of $\mathrm{Fe}_{2} \mathrm{O}_{3}$ content which no pronounced influence on saturation magnetic flux density $\left(\mathrm{B}_{\mathrm{s}}\right)$. However, a slight excess of $\mathrm{Fe}_{2} \mathrm{O}_{3}$ was effective to improve the initial permeability, which could be attributed to decrease of the magnetocrystalline anisotropy. With the increase of sintering temperature, the initial permeability and power loss of the NiZn and NiCuZn ferrites had different trend, which was explained by the grain size and porosity. They reported that the power losses of the NiCuZn ferrite samples were lower than that of the NiZn ferrite samples at any sintering temperature and the NiCuZn ferrites had a better performance than the NiZn ferrites. Bhosale et.al., [48] carried out the initial permeability studies on high density $\mathrm{Cu}-\mathrm{Mg}$-Zn ferrite and based upon the results concluded that variation of initial permeability $\left(\mu_{\mathrm{i}}\right)$ with composition was mainly affected by variation of magnetization $\left(\mathrm{M}_{\mathrm{s}}\right)$ and average particle size. They showed that the initial permeability increased with increase of magnesium content. Effect of copper on the electromagnetic properties of $\mathrm{Mg}-\mathrm{Zn}-\mathrm{Cu}$ ferrites prepared by sol-gel auto combustion method were investigated by Yue et.al., [49] they observed that low temperature sintered $\mathrm{Mg}-\mathrm{Zn}-\mathrm{Cu}$ ferrites possess good electro magnetic properties as well as fine grained microstructure.

Yue et.al., [50] studied the Mn-doped $\mathrm{NiCuZn}$ ferrites with the generic formula $\left(\mathrm{Ni}_{0.2} \mathrm{Cu}_{0.2} \mathrm{Zn}_{0.6}\right) \mathrm{O}\left(\mathrm{Fe}_{2-x}, \mathrm{Mn}_{\mathrm{x}} \mathrm{O}_{3}\right)_{0.98}$ where $\mathrm{x}=0,0.02,0.04$ and 0.06 prepared by a novel sol-gel 
auto combustion process, and found that with increase of Mn content, the initial permeability is significantly increased. Ramana Muthy [51] also studied the low temperature sintered of NiCuZn ferrites with generic formula $\mathrm{Ni}_{0.65-x} \mathrm{Cu}_{x} \mathrm{Zn}_{0.35} \mathrm{Fe}_{2-\mathrm{x}} \mathrm{O}_{4}$ where $\mathrm{x}=1$ to $14 \%$ its electrical, magnetic and elastic properties were investigated, The temperature variation of initial permeability was measured in the temperature range $300-800 \mathrm{~K}$ at a frequency of $1 \mathrm{kHz}$ in a field of $4 \mathrm{~A} / \mathrm{m}$, and found that for higher $\mathrm{Cu}$ content initial permeability increases continuously with temperature. Influence of $\mathrm{PbO}$ on some properties $\mathrm{MgCuZn}$ ferrites were investigated by Sachelarie et.al., [16]. Rezlescu et.al., [15] also studied the influence of $\mathrm{PbO}$ and $\mathrm{Ta}_{2} \mathrm{O}_{5}$ on some properties of $\mathrm{MgCuZn}$ ferrites. Rezlescu et.al., [14] studied the copper ions influence on the physical properties of $\mathrm{MgZn}$ ferrites. Qi et.al., [52] studied a series of $\mathrm{Mn}$ substituted MgCuZn ferrites with generic formula $\left(\mathrm{Mg}_{0.2} \mathrm{Cu}_{0.2} \mathrm{Zn}_{0.6} \mathrm{O}\right)\left(\mathrm{Fe}_{2-x} \mathrm{Mn}_{x} \mathrm{O}_{3}\right)_{0.97}$ with $\mathrm{x}=$ $0.00,0.01,0.03,0.05$ and 0.07 prepared with nanosized precursor powders synthesized by a sol-gel auto-combustion method. All the ceramic samples could be sintered at low temperature $\left(930{ }^{\circ} \mathrm{C}\right.$ ) (below the melt point of $\mathrm{Ag}\left(961^{\circ} \mathrm{C}\right)$ ) and their results showed that low temperature sintered $\mathrm{MgCuZn}$ ferrites doped with $\mathrm{Mn}$ posses higher initial permeability and better grain structure than that of low temperature sintered $\mathrm{NiCuZn}$ ferrites prepared by the same method. Therefore, Mn doped MgCuZn ferrites should be ideal materials for high inductance multilayer chip inductor. It is thought that the variation of initial permeability of $\mathrm{MgCuZn}$ ferrites with the Mn substitution was attributed to the decrease of magnetostriction constant.

Preparation of low-power loss $\mathrm{MgCuZn}$ ferrites using the microwave sintering method were studied by Bhaskar et.al., [53]. Hyie et.al., [54] carried out the studies on the electromagnetic properties of various compositions of magnesium-copper-zinc ferrites and suggested that good electromagnetic properties of $\mathrm{MgCuZn}$ ferrites were attributed to low $\mathrm{MgO}$, moderate $\mathrm{CuO}$ and high $\mathrm{ZnO}$ contents. Roy and Bera [55] studied the effect of $\mathrm{Mg}$ substitution on electromagnetic properties of $\left(\mathrm{Ni}_{0.25-x} \mathrm{Mg}_{x} \mathrm{Cu}_{0.2} \mathrm{Zn}_{0.55}\right) \mathrm{Fe}_{2} \mathrm{O}_{4}$ with $\mathrm{x}=0.0,0.07,0.13,0.18$, and 0.25 synthesized through nitrate-citrate auto-combustion method. The initial permeability was measured in the frequency range $10 \mathrm{~Hz}-10 \mathrm{MHz}$ and the permeability were found to increase and the magnetic loss decreased with $\mathrm{Mg}$ substitution for $\mathrm{Ni}$, up to $\mathrm{x}=0.18$ and also observed a very high permeability in the composition $x=0.18$, which was due to better densification, lower magnetostriction constant and inner stresses, etc., and concluded that this composition would be better than NiCuZn-based material for more miniaturization of multi layer chip inductors.

Low and Sale et.al., [56] studied the development and analysis of property composition diagrams on gel-derived stoichmetric NiCuZn ferrite. As the sintering temperature increases, the reduction in resistivity is attributed to the formation of $\mathrm{BiCu}_{2} \mathrm{O}_{4}$ at grain boundaries which has lower resistivity compared to that of ferrite materials. The effects of $\mathrm{Cu}$ substitution for $\mathrm{Mg}$ on the properties of $\mathrm{MgZn}$ ferrite sintered at low temperature was investigated by Rezlescu et.al., [57]. Park et.al., [58] studied the effect of $\mathrm{WO}_{3}$ addition on the electrical and magnetic properties of $\left(\mathrm{Ni}_{\mathrm{x}} \mathrm{Cu}_{0.2} \mathrm{Zn}_{0.8-\mathrm{x}} \mathrm{O}\right)_{1.02}\left(\mathrm{Fe}_{2} \mathrm{O}_{3}\right)_{0.98}$ sintered at low temperature. They found that the addition of small amount (below $1 \mathrm{wt} \%$ ) of $\mathrm{WO}_{3}$ improves their electrical and magnetic properties. Zhang et.al., [59] carried out the investigation on structure and proper- 
ties of low temperature sintered composite ferrites: viz., $\left(\mathrm{Ni}_{0.60} \mathrm{Zn}_{0.20} \mathrm{Cu}_{0.20}\right) \mathrm{Fe}_{2} \mathrm{O}_{4}$ spinel ferrite powder and $\mathrm{Co}_{2} \mathrm{Z}$ were synthesized by self propagating method. They observed that the composite ferrites have excellent electromagnetic properties in hyper frequencies more than $1.5 \mathrm{GHz}$.

Qi et.al., [60] investigated the magnetic properties of composite materials with a ferrimagnetic $\mathrm{Ni}_{0.2} \mathrm{Cu}_{0.2} \mathrm{Zn}_{0.6} \mathrm{Fe}_{1.96} \mathrm{O}_{4}$ phase and a ferro electric $\mathrm{BaTiO}_{3}$ phase with generic formula 1-x $\left(\mathrm{Ni}_{0.2} \mathrm{Cu}_{0.2} \mathrm{Zn}_{0.6} \mathrm{Fe}_{1.96} \mathrm{O}_{4}\right)-\mathrm{x}\left(\mathrm{BaTiO}_{3}\right)$ composites in which $\mathrm{x}$ varies from 0 to 1 . They found that the saturation magnetization and initial permeability decreases with increasing ferroelectric content $\mathrm{BaTiO}_{3}$ phase. Aoki et.al., [61] studied the bending strength of sintered ferrites for $\mathrm{MgCuZn}-\mathrm{NiCuZn}$ and $\mathrm{MnZn}$ ferrites and observed that residual carbon content affects bending strength of these sintered ferrites and the sintered ferrites containing much residual carbon lower the bending strength. Nakano and Nomura [62] carried out the studies on low temperature sintered $\mathrm{NiCuZn}$ ferrites used for multilayer ferrite chips.

Effect of manganese impurity on the magnetic properties of $\mathrm{Ni}_{0.3} \mathrm{Mn}_{\mathrm{x}} \mathrm{Zn}_{0.7 \mathrm{x}} \mathrm{Fe}_{2} \mathrm{O}_{4}$ in which $\mathrm{x}$ varies from 0.1 to 0.5 , were studied by Amarendra et.al., [63] and they concluded that the initial permeability continuously decreases with increase in manganese content. Srinivasan et.al., [64] carried out the studies on high density nickel zinc ferrites $\mathrm{Ni}_{1-x} \mathrm{Zn}_{x} \mathrm{Fe}_{2} \mathrm{O}_{4}$ and its magnetic properties using novel hydrazine precursor method. Low-temperature sintering method for $\mathrm{NiCuZn}$ ferrite and the effect of Mn addition on electromagnetic properties were carried out by Ju and Pian [65]. Zhang et.al., [66] studied the preparation and investigation of $\left(\mathrm{Ni}_{0.15} \mathrm{Cu}_{0.25} \mathrm{Zn}_{0.6}\right) \mathrm{Fe}_{1.96} \mathrm{O}_{4}$ ferrite with very high initial permeability from self-propagated powders and found that the sintered ferrite specimens have very high initial permeability. They also found that densification of the ferrites and homogeneous grain growth were the main factors affecting high initial permeability. Kim et.al., [67] studied structure and mossbauer studies of $\mathrm{Cu}$ doped NiZn ferrites.

Tsay et.al., [68] studied the microwave sintering technique of NiCuZn ferrites materials with generic formula $\left(\mathrm{Ni}_{1-\mathrm{x}-\mathrm{y}} \mathrm{Zn}_{\mathrm{x}} \mathrm{Cu}_{\mathrm{y}} \mathrm{Fe}_{2} \mathrm{O}_{4}\right)$ and multi layer chip inductors. They concluded that the benefit of using microwave sintering is in densifying multilayer chip inductors. They could achieve high-impedance multilayer chip inductors by microwave sintering of the materials at $800-850^{\circ} \mathrm{C}$ for 20 minutes. Wang et.al., [69] studied the effects in processing in the densification and properties of low temperature sintered $\mathrm{NiCuZn}$ ferrites.

Nakamura [5] reported low temperature sintering of $\mathrm{NiZnCu}$ ferrite and its permeability spectra and concluded that the post sintering density and complex permeability of $\mathrm{NiZnCu}$ ferrite ceramics can be controlled by altering the particle size of the starting oxide materials and the calcination temperature. The complex permeability of sintered ferrite is described as the summation of the spin rotational contribution and domain wall motion. The permeability in $100 \mathrm{MHz}$ region is determined mainly by the spin rotation magnetization mechanism and it depends only on the ferrite volume loading.

Wu et.al., [70] studied the preparation of $\mathrm{NiZn}$ ferrites $/ \mathrm{SiO}_{2}$ nano composite powders by solgel auto combustion method. Ladgaonkar [71] investigated the initial permeability studies of $\mathrm{Nd}^{3+}$ substituted $\mathrm{Zn}-\mathrm{Mg}$ ferrite system and explained that on substitution of $\mathrm{Nd}^{3+}$ ion 
causes reduction in the magnetic moment and curie temperatures. Substituted $\mathrm{Nd}^{3+}$ ion shows its occupancy on tetrahedral (B) site, and explained the positive contribution to the anisotropy constant $\mathrm{K}_{1}$.

Bhosale et.al., [72] studied the initial permeability on high density CuMgZn ferrites and explained the variation in initial permeability was mainly affected by variations of magnetization $\left(\mathrm{M}_{\mathrm{s}}\right)$ and average particle size. The $\mu_{\mathrm{i}}$ decreases with increasing $\mathrm{Mg}^{2+}$ content. This is attributed to a lower value of the anisotropy constant $\left(\mathrm{K}_{1}\right)$ for $\mathrm{MgFe}_{2} \mathrm{O}_{4}$ than that of $\mathrm{CuFe}_{2} \mathrm{O}_{4}$. Ghodake et.al., [73] studied the magnetic properties of $\mathrm{Mn}$ substituted $\mathrm{Mg}-\mathrm{Zn}$ ferrites and they explain the decrease in Curie temperature $\left(T_{c}\right)$ with addition of manganese in terms of the exchange interaction. The decrease in permeability with the addition of $\mathrm{Ti}^{4+}$ in $\mathrm{Mg}-\mathrm{Zn}$ ferrite system was reported by Suryavanshi et.al., [74]. A variation of $\mathrm{K}_{1}$ has been explained on the basis of cation distribution. The relaxation phenomenon and frequency dispersion of complex permeability have been investigated in system of $\mathrm{MgCuZn}$ ferrites by Umeda et.al., [75]. Krishnaveni et.al., [76] studied the microwave hydrothermal synthesis and characterization of nanosized $\mathrm{NiCuZn}$ ferrites.

Ladgaonkar et.al., [77] studied the influence of $\mathrm{Nd}^{3+}$ substitution on the permeability spectrum in $\mathrm{Zn}-\mathrm{Mg}$ ferrites with generic formula $\mathrm{Zn}_{\mathrm{x}} \mathrm{Mg}_{1-\mathrm{x}} \mathrm{Fe}_{2-\mathrm{y}} \mathrm{Nd}_{\mathrm{y}} \mathrm{O}_{4}$ where $\mathrm{x}=0.00,0.20,0.40$, $0.60,0.80$ and 1.00, $y=0.00,0.05$ and 1.00. The frequency dependence of initial permeability was measured by them in the frequency range from $100 \mathrm{~Hz}$ to $1 \mathrm{MHz}$, Their study reveals dispersion in initial permeability and the dispersion frequency was found to be lower for the high permeability compositions than the lower permeability compositions. Atassi and Tally [78] studied the low temperature sintering of $\mathrm{MgCuZn}$ ferrites prepared by citrate precursor method and found that sintering process increases the crystallinity of the solid and its domain size.

Effects of composition and sintering temperature on grain size, porosity and magnetic properties of the NiZn and NiCuZn ferrites were investigated by su et.al., [79] and they found that the lowest power loss could be obtained with the equimolar composition for both NiZn and NiCuZn ferrites, which was attributed to the lowest porosity in those samples. A slight deficiency or excess of $\mathrm{Fe}_{2} \mathrm{O}_{3}$ content had no pronounced influence on saturation magnetic flux density $\left(\mathrm{B}_{\mathrm{s}}\right)$ in their testing range. However, a slight excess of $\mathrm{Fe}_{2} \mathrm{O}_{3}$ was effective to improve the initial permeability, which could be attributed to decrease of the magnetocrystalline anisotropy. With the increase of sintering temperature, the initial permeability and power loss of the NiZn and NiCuZn ferrites showed increasing trend, which was explained by the variation of the grain sizes and porosities. Their observation shows that the power losses of the NiCuZn ferrite samples were lower than that of the NiZn ferrite samples at any sintering temperature. The NiCuZn ferrites had a better performance than the NiZn ferrites in power applications. Bhosale et.al., [80] studied the synthesis of $\mathrm{Cu}-\mathrm{Mg}-\mathrm{Zn}$ ferrites and correlation of magnetic properties with microstructure with a generic formula $\mathrm{Cu}_{0.5-\mathrm{x}}$ $\mathrm{Mg}_{\mathrm{x}} \mathrm{Zn}_{0.5} \mathrm{Fe}_{2} \mathrm{O}_{4}$ where $\mathrm{x}=0.00,0.20,0.25$ and 0.40 and observed that initial permeability of all the samples increases with increase in temperature and $\mathrm{Mg}^{2+}$ content upto $(x \leq 0.20)$.

Zahi et.al., [81] investigated the synthesis, magnetic properties and micro structure of Ni-Zn ferrite with generic formula $\mathrm{Ni}_{0.3} \mathrm{Zn}_{0.7} \mathrm{Fe}_{2} \mathrm{O}_{4}$ by sol-gel technique using metal acetates at low 
temperature and they observed that initial permeability increases in the large frequency band (31MHz). Ghodake et.al., [82] studied the magnetic properties of NiCuZn ferrites synthesized by oxalate precursor method with generic formula $\mathrm{Ni}_{\mathrm{x}} \mathrm{Cu}_{[(1-\mathrm{t} t)-\mathrm{x}]} \mathrm{Zn}_{\mathrm{t}} \mathrm{Fe}_{2}\left(\mathrm{C}_{2} \mathrm{O}_{4}\right) \cdot \mathrm{nH}_{2} \mathrm{O}$ (where $t=0.45,0.50,0.55,0.60$ and $x=0.00,0.05,0.10,0.15,0.20,0.30,0.40,0.50$, and 0.55) in the temperature range 30 to $240{ }^{\circ} \mathrm{C}$ and in the frequency range from $20 \mathrm{~Hz}$ to $700 \mathrm{kHz}$. Initial permeability $\left(\mu_{\mathrm{i}}\right)$ shows increase with addition of $\mathrm{Ni}^{2+}$ up to $\mathrm{x}=0.15$ while for $(x>0.15)$, it decreases. The increase in initial permeability $\left(\mu_{\mathrm{i}}\right)$ is attributed to monotonic increase in $\mathrm{M}_{\mathrm{s}^{\prime}}$ and $\mathrm{K}_{1}$ on addition of $\mathrm{Ni}^{2+}$. However, the microstructure and density (porosity) also influence the $\mu_{i}$ variations. The decrease in $\left(\mu_{i}\right)$ is attributable to increase of $K_{1}$.

$\mathrm{Hu}$ et.al., [83] carried out the studies on the effect of magnetic permeability of $\left(\mathrm{Ni}_{0.21} \mathrm{Zn}_{0.58} \mathrm{Cu}_{0.23}\right) \mathrm{Fe}_{1.95} \mathrm{O}_{4}$ prepared by sol-gel self-propagating method. With this method of low temperature fired NiCuZn ferrite obtained as an initial permeability of 1120 and quality factor Q of 84 at $100 \mathrm{kHz}$. Byu et.al., [84] studied the factors effecting the initial permeability of Co-substituted $\mathrm{Ni}-\mathrm{Cu}-\mathrm{Zn}$ ferrites in the iron deficient composition of $\left(\mathrm{Ni}_{0.2} \mathrm{Cu}_{0.2} \mathrm{Zn}_{0.6}\right)_{1.02-x} \mathrm{Co}_{\mathrm{x}} \mathrm{Fe}_{1.98} \mathrm{O}_{4}$ where $\mathrm{x}$ varies between 0 and 0.05 prepared to investigate the initial permeability dependence on cobalt contents. The compositional variation of initial permeability in cobalt substituted $\mathrm{Ni}-\mathrm{Zn}-\mathrm{Cu}$ ferrites could not be explained fully by intrinsic factors such as saturation magnetization and magnetic anisotropy based on a one-ion model. There results show that in addition to the magnetocrystalline and magnetoelastic anisotropy, the increase in induced anisotropy with increasing Co content results in the decrease of initial permeability.

Yue et.al., [85] studied the low sintered Mn-doped NiCuZn ferrites with compositions of $\left(\mathrm{Ni}_{0.25-\mathrm{x}} \mathrm{Mn}_{\mathrm{x}} \mathrm{Cu}_{0.25} \mathrm{Zn}_{0.5}\right) \mathrm{O}\left(\mathrm{Fe}_{2} \mathrm{O}_{3}\right)_{0.98}$ where $\mathrm{x}=0.02,0.04,0.06,0.08,0.10$ were prepared by usual ceramic method. Initial permeabilities $\left(\mu_{\mathrm{i}}^{\prime}\right.$ and $\left.\mu_{\mathrm{i}}^{\prime \prime}\right)$, were measured as a function of frequency and temperature. They reported that with increase in $\mathrm{MnO}_{2}$ content, the resonant frequency and the Curie temperature decreased, whereas the $\mu_{i}^{\prime}$ increases at low concentrations and decreases for higher concentration showing a maximum at $\mathrm{MnO}_{2}$ for $\mathrm{x}=0.06$.

$\mathrm{Hu}$ and Yan [86] studied the preparation of high permeability NiCuZn ferrite with generic formula $\left(\mathrm{Ni}_{0.17} \mathrm{Zn}_{0.63} \mathrm{Cu}_{0.20}\right) \mathrm{Fe}_{1.915} \mathrm{O}_{4}$ by sintering at $930^{\circ} \mathrm{C}$ it showed an initial permeability of 1700 and relative loss coefficient tan $\delta / \mu$ i of $9.0 \times 10^{-6}$ at $100 \mathrm{kHz}$, due to the appropriate addition of $\mathrm{CuO} / \mathrm{V}_{2} \mathrm{O}_{5}$ and showed a decrease in granularity of particles. Tantalum oxide added $\mathrm{MgCuZn}$ ferrite powders [87] were synthesized by a co-precipitation method using $\mathrm{NaOH}$ in a microwave-hydrothermal method. They showed the variation of initial permeability as a function of additive concentration at room temperature. Bhaskar et.al., [88] carried out studies on low temperature sintered Mn added $\mathrm{MgCuZn}$ ferrites were prepared using microwave sintering method and room temperature property of quality factor and initial permeability have been measured in the frequency range of $100 \mathrm{kHz}-100 \mathrm{MHz}$. The initial permeability was also measured in the temperature range of 300-650 K. Murase et.al., [89] studied the state of impurities, grain growth behavior and magnetic characteristics in $\mathrm{MgZn}$ ferrites. 
Krishnaveni and Ramana Murthy [90] studied the microwave hydrothermal synthesis of nanosized $\mathrm{Ta}_{2} \mathrm{O}_{5}$ added $\mathrm{Mg}-\mathrm{Cu}$ - $\mathrm{Zn}$ ferrites. Its initial permeability as a function of additive at room temperature was investigated and observed that the prepared microinductors posses better electrical properties than the microinductors prepared by using the NiCuZn ferrites. Mukesh et.al., [91] studied the effect of substitution of cations by cobalt in small concentration on the magnetic properties at low and high frequencies, in the polycrystalline ferrite samples having the composition $\left(\mathrm{Ni}_{0.2} \mathrm{Cu}_{0.2} \mathrm{Zn}_{0.6}\right)_{1-\mathrm{x}} \mathrm{Co}_{\mathrm{x}} \mathrm{Fe}_{2} \mathrm{O}_{4}$, where $\mathrm{x}=0,0.01,0.03$ and 0.05 , they were prepared by citrate precursor method. Complex permittivity and permeability were measured at microwave frequencies (X-band) using the cavity perturbation method, which is a non-contact method.

Hsu et.al., [92] verified the addition of nanocrystalline ferrite particles (NFPs) was effective in improving the densification behavior and magnetic properties of the NiCuZn ferrites for multilayer chip inductor (MLCI) applications. The NFPs, which have high surface free energy, spread around the micron-sized ferrite particles (MFPs) and increased contacting area and inter-diffusion of the particles. They observed that the sample with $30 \mathrm{wt} \%$ NFPs additive exhibited the highest initial permeability when sintered at $900{ }^{\circ} \mathrm{C}$, than that made by the ferrite with $1.5 \mathrm{wt} \% \mathrm{Bi}_{2} \mathrm{O}_{3}$ due to less diffusion of $\mathrm{Ag}$ electrode to ferrite and higher initial permeability. It was mainly attributed to relatively larger grain size and higher sintering density.

Su et.al., [93] carried out the studies on high-permeability and high-Curie temperature Ni$\mathrm{CuZn}$ ferrite. In this process, attention was focused on the amount of $\mathrm{CuO}$ contained in NiZn ferrite and a small additive of $\mathrm{MoO}_{3}$ added in the NiCuZn ferrite and observed that the initial permeability of the core increased and the Curie temperature only decreased a little with $4 \mathrm{~mol} \% \mathrm{CuO}$ content. This was mainly attributed to the presence of $\mathrm{Cu}$ ions activating the sintering processes in ferrites and leading to increase in density. The decrease of magnetocrystalline anisotropy constant also does some contribution, by optimizing the $\mathrm{MoO}_{3}$ as additive, the initial permeability could get a sharp increase because of enhancement of grain size. So in the NiCuZn ferrite with a permeability of 2480 and Curie temperature of around $118{ }^{\circ} \mathrm{C}$ was obtained and by optimizing the $\mathrm{CuO}$ content, the initial permeability of the cores was increased and the Curie temperature decrease was only a little. This was attributed to the appropriate $\mathrm{MoO}_{3}$ having the effect of promoting crystalline grain growth and not forming the abnormal grain growth and closure of pores.

Wang et.al., [94] prepared nano-sized NiCuZn ferrite powders with a composition of $\left(\mathrm{Ni}_{0.15} \mathrm{Cu}_{0.2} \mathrm{Zn}_{0.65} \mathrm{O}\right)\left(\mathrm{Fe}_{2-\mathrm{x}} \mathrm{Mn}_{\mathrm{x}} \mathrm{O}_{3+0.5 \mathrm{x}}\right)_{0.99}$ where $\mathrm{x}=0$ to 0.04 , and studied the effect of Mn dopant on the microstructures and the initial permeability. They observed that introduction of $\mathrm{Mn}$ into NiCuZn ferrite has a great influence on its electromagnetic properties. i.e., initial permeability of $\mathrm{NiCuZn}$ ferrite increases greatly with a small amount of Mn addition, and then further increase of Mn content leads to a decrease in the initial permeability.

The effect of $\mathrm{Mn}$ substitution on the magnetic properties and microstructure of the $\left(\mathrm{Ni}_{0.2} \mathrm{Cu}_{0.2} \mathrm{Zn}_{0.6}\right)_{1.03}\left(\mathrm{Fe}_{2} \mathrm{O}_{3}\right)_{0.97}+0.97 \times \mathrm{MnO}_{2}$ where $\mathrm{x}=0.1$ to 0.5 , were investigated by $\mathrm{Li}$ et.al., [95]. They observed that Mn content increases the initial permeability. Gao et.al., [96] studied solenoid type inductor with ultra low profile was fabricated by micro electromechnical 
system (MEMs) in which NiFe was electroplated as the magnetic core, and measured the value of inductance and quality factor. They observed $0.42 \mu \mathrm{H}$ and 1.8 at $1 \mathrm{MHz}$, while the quality factor is 5.3 with inductance value of $0.345 \mu \mathrm{H}$ at $10 \mathrm{MHz}$.

Micro structural dependence of permeability and permittivity spectra in Ni- $\mathrm{Zn}$ ferrites with generic formula $\mathrm{Ni}_{0.4} \mathrm{Zn}_{0.6} \mathrm{Fe}_{2} \mathrm{O}_{4}$ doped with $\mathrm{V}_{2} \mathrm{O}_{5}$ and $\mathrm{Bi}_{2} \mathrm{O}_{3}$ were studied by Pyun and Beak [97] and they explained that the initial permeability increases linearly with the grain size up to $5.9 \mu \mathrm{m}$ and then decreases for undoped ferrite specimens, where as it increases linearly with the grain size for $\mathrm{V}_{2} \mathrm{O}_{5}$ doped ferrite specimens. The decrease in permeability with increase in grain size for undoped ferrite specimens was discussed in terms of the formation of excess $\mathrm{Fe}^{2+}$ due to higher equilibrium oxygen pressure.

\section{Review of the previous experimental work on the stress sensitivity of ferrites}

Stress sensitivity of inductance in NiCuZn ferrites was carried out by Ramamanohar Reddy et.al., [38] and observed that stress sensitivity is more in the case of iron rich and stoichiometric iron samples while in the case of iron deficient samples the stress sensitivity was found to be less. The stress sensitivity in Ni-Mn, Ni-Mn-Co and Ni-Mn-Co-Cu ferrites was studied by Kaczkowski [98] and he concluded that the greatest stress sensitivity was observed for the ferrites with the smallest magnetocrystalline anisotropy.

The effects of chemical composition and micro structure on stress sensitivity of magnetic properties to applied stress of $\mathrm{Ni}-\mathrm{Mg}-\mathrm{Cu}-\mathrm{Zn}$ ferrite materials were investigated by Kanada et.al., [27] and they found that the application of external stress reduces the permeability Mechanical and electrical properties of $\mathrm{Ni}_{0.65} \mathrm{Zn}_{0.35} \mathrm{Cu}_{x} \mathrm{Fe}_{2-x} \mathrm{O}_{4}$ ferrites were carried out by Abd.El-Ati and Tawfik [99]. Enokido et.al., [100] studied the effects of additives on the stress variation and temperature dependence of inductance in NiCuZn ferrite. Effect of glass addition and quenching on the relation between inductance and external compressive stress in $\mathrm{Ni}-\mathrm{Cu}-\mathrm{Zn}$ ferrite-glass composites were reported by $\mathrm{Ya}$ maguchi and Shingawa [101]. Developments of stress-insensitive ferrite were carried out by Ikeda and Kumagi [102] and concluded that the sensitivity of the magnetic property to the external stress in $\mathrm{NiCuZn}$ ferrite was examined from the relationship between stress and permeability. They found that in the mass production process of inductors, when external stress is applied to the NiCuZn ferrite core by moulding them in resin, which is a protection against humidity or shock. It reduces inductance magnitudes as the permeability of $\mathrm{NiCuZn}$ ferrites is very sensitive to the external stress, the inductance of inductors changes very easily by the applied stress. This change has been recognized as the barrier to produce the inductors with a narrow inductance tolerance and found the best way to control the stress-sensitivity of permeability in NiCuZn ferrite was the addition of oxides such as $\mathrm{SiO}_{2}$, the change in the inductance could be completely explained from the residual stress caused by the difference of coefficients of linear thermal expansion between spinel phase (magnetic) and second phase (non- 
magnetic). By this process, they succeeded in developing "stress-insensitive ferrite". Nakano et.al., [18] studied the development of low temperature fired NiCuZn ferrites, they studied the high performance for multilayer chip inductors and concluded that controlling stress by the internal Ag-conductor and $\mathrm{CuO}_{1-\mathrm{x}} / \mathrm{Ag}$ on ferrites grain boundary is most important key point for high performance multilayer chip ferrites as well as the chemical composition of ferrite. The stress insensitive ferrite for micro inductors was carried out by Kumagi and Ikeda. [103]. Nakano et.al., [104] investigated the electro magnetic properties of low temperature sintered $\mathrm{Mg}-\mathrm{Cu}-\mathrm{Zn}$ ferrites and observed that under a compressive stress, the change in permeability of low temperature sintering $\mathrm{MgCuZn}$ ferrite was lower than that of low temperature sintering NiCuZn ferrite, also the multilayer chip inductor using low temperature sintering $\mathrm{MgCuZn}$ ferrite would show a higher inductance than the chip using low temperature sintered $\mathrm{NiCuZn}$ and low temperature sintering $\mathrm{MgCuZn}$ ferrite has the high potentialities of useful materials in the multilayer chip ferrite components.

The effect of $\mathrm{SiO}_{2}$ on the bending strength of $\mathrm{NiCuZn}$ ferrite was investigated by Aoki et.al., [105] and they found that the bending strength of NiCuZn ferrite was increased by the addition of $\mathrm{SiO}_{2}$. Also, the $\mathrm{NiCuZn}$ ferrite with $\mathrm{SiO}_{2}$ addition showed a structure with smaller and more uniform grain size than non-addition. The improvement in the bending strength of NiCuZn ferrite was attributed to the control of grain growth by $\mathrm{Zn}_{2} \mathrm{SiO}_{4}$, and the residual stress caused by the difference of coefficients of linear thermal expansion between ferrite phase and $\mathrm{Zn}_{2} \mathrm{SiO}_{4}$ phase.

Aoki et.al., [106] studied the bending strength of sintered ferrites for $\mathrm{MgCuZn-NiCuZn}$ and MnZn ferrites. They found that the residual carbon content affects bending strength of these ferrites more over, sintered ferrites, containing much residual carbon lowers the bending strength. Fujimoto [107] studied the inner stress induced by $\mathrm{Cu}$ metal precipitation at grain boundaries in low temperature fired $\mathrm{Ni}-\mathrm{Zn}-\mathrm{Cu}$ ferrite.

From the above review, the author noticed that the experimental work carried out on ferrite composites is scanty. In view of this, the author has taken up a detailed study of initial permeability in pure components $\mathrm{Mg}_{0.25} \mathrm{Cu}_{0.1} \mathrm{Zn}_{0.5} \mathrm{Fe}_{2} \mathrm{O}_{4}$ and $\mathrm{Ni}_{0.35} \mathrm{Cu}_{0.05} \mathrm{Zn}_{0.6} \mathrm{Fe}_{2} \mathrm{O}_{4}$ and their composites with $\mathrm{x}=0.2,0.4,0.5,0.6$ and 0.8 at a frequency of $1 \mathrm{kHz}$ and temperature range 25 to $250{ }^{\circ} \mathrm{C}$. The stress sensitivity studies on the pure components and equimolar mixture of these components were also studied and the results are presented in the following section.

\section{Results and discussion}

a. X-ray diffractogram analysis

Pure ferrites and their composites sintered at $1250{ }^{\circ} \mathrm{C}$ confirm the formation of single phase cubic structure. 
An observation from the Fig.1 shows that the (222), (111) (511) and (440) peaks which belong to octahedral and tetrahedral sites are maximum suppressed in the equimolar composition of ferrite composite i.e for $\mathrm{x}=0.5$, when compared to pure ferrite components. And also it can be noticed that the intensity of (311) peak is maximum in equimolar composition when compared to pure ferrite components.

Pure ferrites and their composites sintered at $1250{ }^{\circ} \mathrm{C}$ confirm the formation of single phase cubic structure.

An observation from the Fig.1 shows that the (222), (111) (511) and (440) peaks which belong to octahedral and tetrahedral sites are maximum suppressed in the equimolar composition of ferrite composite i.e for $x=0.5$, when compared to pure ferrite components. And also it can be noticed that the intensity of (311) peak is maximum in equimolar composition when compared to pure ferrite components.

b. Scanning electron micrographic (SEM) studies

The scanning electron micrograph for $\mathrm{Mg}_{0.25} \mathrm{Cu}_{0.25} \mathrm{Zn}_{0.5} \mathrm{Fe}_{2} \mathrm{O}_{4}$ shows a systematic grain structure (shown in Fig.2) having clear grain boundaries. The initial permeability $\left(\mu_{\mathrm{i}}\right)$ is comparatively low. For $\mathrm{x}=0.4$ (not shown in Fig) composition shows a discontinuous grain structure with out any voids having large grain size.

On the other hand, the micrograph of ferrite composite with $x=0.5$ (shown in Fig.2b). It is interesting to note that the morphology of grains is different from That of pure components. However, the initial permeability obtained in this composite is fairly high.

The micrograph of $\mathrm{Ni}_{0.35} \mathrm{Cu}_{0.05} \mathrm{Zn}_{0.6} \mathrm{Fe}_{2} \mathrm{O}_{4}$ composition (shown in Fig.2c). it can be very clearly seen that the morphology o fgrains in this sample is different from that $\mathrm{Mg}_{0.25} \mathrm{Cu}_{0.25} \mathrm{Zn}_{0.5} \mathrm{Fe}_{2} \mathrm{O}_{4}$

\subsection{Initial permeability}

\section{a. Composition dependence of initial permeability}

The initial permeability $\left(\mu_{\mathrm{i}}\right)$ as function of composition at room temperature $\left(30{ }^{\circ} \mathrm{C}\right)$ for various mole fractions of ferrite composites along with their curie temperatures $\left(\mathrm{T}_{c}\right)$ is graphically represented in Fig.4. It can be noticed from the figure that with increasing $\mathrm{x}$ the initial permeability magnitudes reaches a maximum value at equimolar composition. i.e., 0.5 $\left(\mathrm{Mg}_{0.25} \mathrm{Cu}_{025} \mathrm{Zn}_{0.5} \mathrm{Fe}_{2} \mathrm{O}_{4}\right)+0.5\left(\mathrm{Ni}_{0.35} \mathrm{Cu}_{0.05} \mathrm{Zn}_{0.6} \mathrm{Fe}_{2} \mathrm{O}_{4}\right)$ and there after it decreases. The initial permeability values of pure ferrites are 1040 and 1090 in $\mathrm{Mg}_{0.25} \mathrm{Cu}_{0.25} \mathrm{Zn}_{0.5} \mathrm{Fe}_{2} \mathrm{O}_{4}$ composition and $\mathrm{Ni}_{0.35} \mathrm{Cu}_{0.05} \mathrm{Zn}_{0.6} \mathrm{Fe}_{2} \mathrm{O}_{4}$ composition respectively. The permeability of equimolar mixture shows a magnitude of 9619 . However, the Curie temperature of these composites linearly decreases with in increase in $x$ i.e., $\mathrm{Ni}_{0.35} \mathrm{Cu}_{0.05} \mathrm{Zn}_{0.5} \mathrm{Fe}_{2} \mathrm{O}_{4}$ composition. Fig. 4 shows the variation of excess initial permeability $\mu^{\mathrm{E}}$ and excess volume $\mathrm{V}^{\mathrm{E}}$ for ferrite composites

The permeability and molar volume show high values of at equimolar composition. This property can be explained to achieve high permeability ferrites. This is the excess property of the mixtures. 


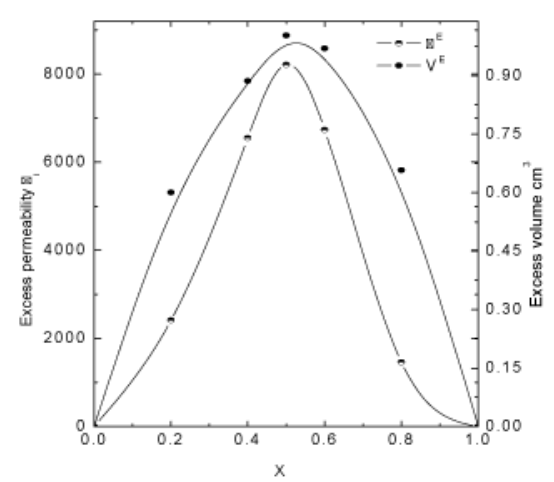

Figure 4. Variation of excess initial permeability $\left(\mu_{\mathrm{i}}^{\mathrm{E}}\right)$ and excess volume $\left(\mathrm{V}^{\mathrm{E}}\right)$ of the system with increasing $\mathrm{X}$.

b. Temperature dependence of initial permeability

The plots of initial permeability $\left(\mu_{\mathrm{i}}\right)$ with temperature in the temperature range $30{ }^{\circ} \mathrm{C}$ to $250{ }^{\circ} \mathrm{C}$ for various compositions of the ferrite composite system is shown in the Fig.5. As the temperature increases the initial permeability remains flat upto a particular temperature and suddenly falls to a minimum value in all the composites except in equimolar composition. In equi molar composition the initial permeability gradually decreases upto Curie temperature and there after it suddenly falls to zero value.

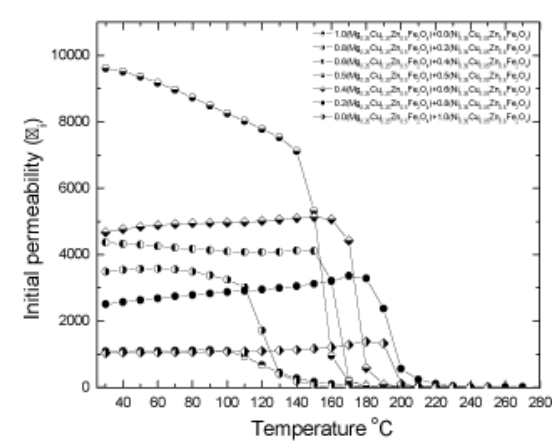

Figure 5. Variation of initial permeability $\left(\mu_{\mathrm{i}}\right)$ with temperature at room temperature for the ferrite composites.

The increase of $\mu_{\mathrm{i}}$ with temperature is explained as follows: The anisotropy field usually decrease with temperature much faster than $\mathrm{M}_{\mathrm{s}}$. The high value of $\mu_{\mathrm{i}}$ corresponds to zero point in anisotropy, caused by presence of $\mathrm{Fe}^{2+}$ ions in the sample. 


\subsection{Stress sensitivity}

In pure component $\left(\mathrm{Mg}_{0.25} \mathrm{Cu}_{0.25} \mathrm{Zn}_{0.5} \mathrm{Fe}_{2} \mathrm{O}_{4}\right.$ and $\left.\mathrm{Ni}_{0.35} \mathrm{Cu}_{0.05} \mathrm{Zn}_{0.6} \mathrm{Fe}_{2} \mathrm{O}_{4}\right)$ and their equimolar composite i.e., $0.5\left(\mathrm{Mg}_{0.25} \mathrm{Cu}_{0.25} \mathrm{Zn}_{0.5} \mathrm{Fe}_{2} \mathrm{O}_{4}\right)+0.5\left(\mathrm{Ni}_{0.35} \mathrm{Cu}_{0.05} \mathrm{Zn}_{0.6} \mathrm{Fe}_{2} \mathrm{O}_{4}\right)$ were chosen to examine the stress sensitivity of inductance in them. The pure composition $\mathrm{Mg}_{0.25} \mathrm{Cu}_{0.25} \mathrm{Zn}_{0.6} \mathrm{Fe}_{2} \mathrm{O}_{4}$ has an initial permeability $\left(\mu_{\mathrm{i}}=1041\right.$ and the other $\mathrm{Ni}_{0.35} \mathrm{Cu}_{0.05} \mathrm{Zn}_{0.6} \mathrm{Fe}_{2} \mathrm{O}_{4}$ has initial permeability value $\mu_{\mathrm{i}}=1090$. where as their equimolar i.e., $0.5\left(\mathrm{Mg}_{0.25} \mathrm{Cu}_{0.25} \mathrm{Zn}_{0.5} \mathrm{Fe}_{2} \mathrm{O}_{4}\right)+0.5$ $\left(\mathrm{Ni}_{0.35} \mathrm{Cu}_{0.05} \mathrm{Zn}_{0.6} \mathrm{Fe}_{2} \mathrm{O}_{4}\right)$ mixture showed high initial permeability value. It is thought worth while to study the stress sensitivity behaviour in this composite. In addition to this stress sensitivity of pure components were also under taken, the ratio of change in inductance with external compressive stress for all the three samples are shown in the Fig.6.

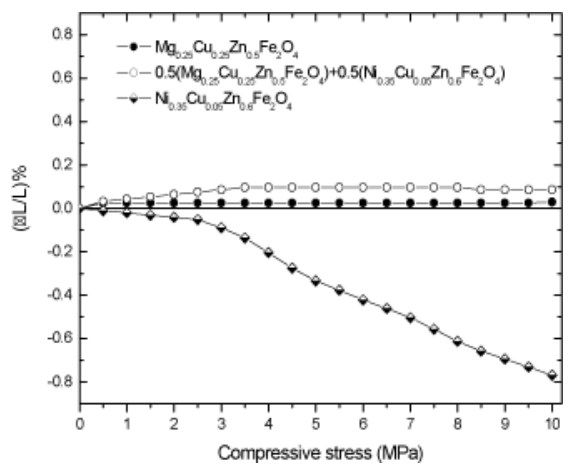

Figure 6. Variation of ratio of change in inductance $(\Delta \mathrm{L} / \mathrm{L}) \%$ as a function of applied compressive stress for the $x=1.0$, 0.5 and 0.0 ferrite composites.

Fig. 6 shows the values of the ratio of inductance change $(\Delta \mathrm{L} / \mathrm{L}) \%$ as a function of applied compressive stress for $\mathrm{Mg}_{0.25} \mathrm{Cu}_{0.25} \mathrm{Zn}_{0.5} \mathrm{Fe}_{2} \mathrm{O}_{4}, \quad \mathrm{Ni}_{0.35} \mathrm{Cu}_{0.05} \mathrm{Zn}_{0.6} \mathrm{Fe}_{2} \mathrm{O}_{4}$ and 0.5 $\left(\mathrm{Mg}_{0.25} \mathrm{Cu}_{0.25} \mathrm{Zn}_{0.5} \mathrm{Fe}_{2} \mathrm{O}_{4}\right)+0.5\left(\mathrm{Ni}_{0.35} \mathrm{Cu}_{0.05} \mathrm{Zn}_{0.6} \mathrm{Fe}_{2} \mathrm{O}_{4}\right)$ composition. From an examination of the Fig. 6 it is clear that these figures indicate that the stress sensitivity is different for pure components and their equimolar mixture.

It is clear that $(\Delta \mathrm{L} / \mathrm{L}) \%$ decreases with increasing applied stress for $\mathrm{Ni}_{0.35} \mathrm{Cu}_{0.05} \mathrm{Zn}_{0.6} \mathrm{Fe}_{2} \mathrm{O}$. But it is found to be more or less insensitive in $\mathrm{Mg}_{0.25} \mathrm{Cu}_{0.25} \mathrm{Zn}_{0.5} \mathrm{Fe}_{2} \mathrm{O}_{4}$. In $\mathrm{Mg}_{0.25} \mathrm{Cu}_{0.25} \mathrm{Zn}_{0.5} \mathrm{Fe}_{2} \mathrm{O}_{4}$ and in equimolar mixture the $(\Delta \mathrm{L} / \mathrm{L}) \%$ values are positive in the entire region of applied stress, while it is negative for $\mathrm{Ni}_{0.35} \mathrm{Cu}_{0.05} \mathrm{Zn}_{0.6} \mathrm{Fe}_{2} \mathrm{O}_{4}$ composition.

This is in agreement with the observations made by Kumagai and Ikeda [103]. For small compressive stresses, the stress raises initial permeability with negative magnetostriction and for large tensile stresses the permeability decreases [108]. The variations of permeability with applied stress can be attributed to the magnetostrictive contributions of varied amounts of nick$\mathrm{el}$ and iron present in these samples. It can be seen from the above figures that in $\mathrm{Mg}_{0.25} \mathrm{Cu}_{0.25} \mathrm{Zn}_{0.5} \mathrm{Fe}_{2} \mathrm{O}_{4}$ the stress sensitivity is found to be less, because magnesium ferrite has low magnetostriction. The eqiumolar mixture shows a broad and blunt peak of $(\Delta \mathrm{L} / \mathrm{L}) \%$ with external compressive stress. A similar trend was observed by kanada et.al., [27]. 
The variation with external compressive stress of $(\Delta \mathrm{L} / \mathrm{L}) \%$ in equimolar mixture is almost negliable and hence the ferrite composite material can be used as stress insensitive core material for microinductor applications.

\section{Conclusions}

\begin{tabular}{|c|c|c|c|c|}
\hline S.No & Author Name & Ref. No. & Studies Carried Out & Observations/Conclusions \\
\hline \multicolumn{5}{|c|}{ Initial Permeability Studies } \\
\hline 1. & Kanada et.al., & [20] & $\begin{array}{l}\text { The replacement of } \mathrm{Fe}_{2} \mathrm{O}_{3} \text { by } \mathrm{Mn}_{2} \mathrm{O}_{3} \\
\text { and replacement of } \mathrm{CuO} \text { for } \mathrm{MgO} \text { in } \\
\mathrm{MgZn} \text { ferrite in order to achieve low } \\
\text { core loss, focusing on the } \\
\text { microstructure. They have also } \\
\text { investigated the initial permeability of } \\
\mathrm{MnZn}, \mathrm{MnMgZn} \text { and MnMgCuZn } \\
\text { ferrites }\end{array}$ & $\begin{array}{l}\text { The initial permeability of both } \\
\text { MnMgZn and MnMgCuZn ferrites } \\
\text { are higher than those of MgZn } \\
\text { ferrite. }\end{array}$ \\
\hline 2. & Yan et.al., & [21] & 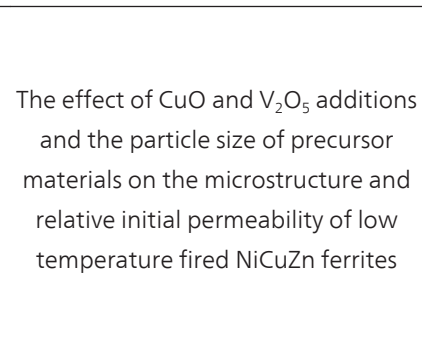 & $\begin{array}{l}\text { The additions of } \mathrm{CuO} \text { and } \mathrm{V}_{2} \mathrm{O}_{5} \\
\text { contribute to the grain growth and } \\
\text { densification of matrix in the } \\
\text { sintering process. Addition of } 10 \\
\text { mol\% CuO and } 0.20 \text { mol\% } \mathrm{V}_{2} \mathrm{O}_{5} \\
\text { favoured the low firing temperature } \\
\text { of NiCuZn ferrite, and showed very } \\
\text { high relative initial permeability of } \\
1417 \text { at } 1 \mathrm{MHz} \text {. }\end{array}$ \\
\hline 3. & Nakamura et.al., & [23] & $\begin{array}{l}\text { The frequency dispersion of } \\
\text { permeability in ferrite composite } \\
\text { materials and observed that } \\
\text { permeability spectra of Ni-Zn ferrite } \\
\text { composite materials. }\end{array}$ & $\begin{array}{l}\text { The sintered ferrite (volume fraction } \\
\text { 1.0), the spin resonance was around } \\
9 \mathrm{MHz} \text { and the static permeability } \\
\text { was about } 1400 \text {. As the ferrite } \\
\text { content decreases in composite } \\
\text { materials, the static susceptibility of } \\
\text { the spin component decreases and } \\
\text { the spin resonance frequency shifts } \\
\text { to higher frequencies. The real part } \\
\text { of the permeability in the ferrite } \\
\text { composite materials becomes larger } \\
\text { than that of the sintered ferrite in } \\
\text { the RF frequency region. }\end{array}$ \\
\hline 4. & Su et.al., & [25] & $\begin{array}{l}\text { The effect of composition and } \\
\text { sintering temperature on grain size, } \\
\text { porosity and magnetic properties of } \\
\text { the NiZn and NiCuZn ferrites. }\end{array}$ & $\begin{array}{l}\text { The lowest power loss could be } \\
\text { obtained with the equimolar } \\
\text { composition for both NiZn and } \\
\text { NiCuZn ferrites, which could be } \\
\text { attributed to the lowest porosity. }\end{array}$ \\
\hline
\end{tabular}




\begin{tabular}{|c|c|c|c|c|}
\hline S.No & Author Name & Ref. No. & Studies Carried Out & Observations/Conclusions \\
\hline \multicolumn{5}{|c|}{ Initial Permeability Studies } \\
\hline 5. & Bhosale et.al., & [28] & $\begin{array}{l}\text { A novel route for the preparation of } \\
\text { high density, high permeability Cu- } \\
\text { Mg-Zn ferrites using oxalate } \\
\text { precursor method, }\end{array}$ & $\begin{array}{l}\text { The initial permeability of all the } \\
\text { samples increased with increase in } \\
\text { sintering temperature and } \mathrm{Mg}^{2+} \\
\text { content for samples with } \mathrm{x} \leq 0.20 \text {. }\end{array}$ \\
\hline 6. & Nam et.al., & [39] & $\begin{array}{l}\text { The effect of Cu substitution on the } \\
\text { properties of NiZn ferrites sintered at } \\
\text { low temperature in various } \\
\text { compositions, }\end{array}$ & $\begin{array}{l}\text { The densification of NiCuZn ferrite is } \\
\text { dependent on Cu content in these } \\
\text { ferrites, }\end{array}$ \\
\hline 7. & Hua Su et.al., & [47] & $\begin{array}{l}\text { Effects of composition and sintering } \\
\text { temperature on grain size, porosity } \\
\text { and magnetic properties of the NiZn } \\
\text { and NiCuZn ferrites }\end{array}$ & $\begin{array}{l}\text { The lowest power loss could be } \\
\text { obtained with the equimolar } \\
\text { composition for both NiZn and } \\
\mathrm{NiCuZn} \text { ferrites, which could be } \\
\text { attributed to the lowest porosity } \\
\text { and a slight deficiency or excess of } \\
\mathrm{Fe}_{2} \mathrm{O}_{3} \text { content which no pronounced } \\
\text { influence on saturation magnetic } \\
\text { flux density }\left(\mathrm{B}_{5}\right) \text {. }\end{array}$ \\
\hline 8. & Bhosale et.al., & [48] & $\begin{array}{l}\text { The initial permeability studies on } \\
\text { high density Cu-Mg-Zn ferrite }\end{array}$ & $\begin{array}{l}\text { Variation of initial permeability }\left(\mu_{\mathrm{i}}\right) \\
\text { with composition was mainly } \\
\text { affected by variation of } \\
\text { magnetization }\left(\mathrm{M}_{\mathrm{s}}\right) \text { and average } \\
\text { particle size. They showed that the } \\
\text { initial permeability increased with } \\
\text { increase of magnesium content. }\end{array}$ \\
\hline 9. & Yue et.al., & [49] & $\begin{array}{l}\text { Effect of copper on the } \\
\text { electromagnetic properties of Mg-Zn- } \\
\text { Cu ferrites prepared by sol-gel auto } \\
\text { combustion method }\end{array}$ & $\begin{array}{l}\text { Low temperature sintered Mg-Zn- } \\
\text { Cu ferrites possess good electro } \\
\text { magnetic properties as well as fine } \\
\text { grained microstructure. }\end{array}$ \\
\hline 10. & Yue et.al., & {$[50]$} & $\begin{array}{l}\text { the Mn-doped NiCuZn ferrites } \\
\text { prepared by a novel sol-gel auto } \\
\text { combustion process, }\end{array}$ & $\begin{array}{l}\text { With increase of Mn content, the } \\
\text { initial permeability is significantly } \\
\text { increased. }\end{array}$ \\
\hline 11. & Ramana Muthy & [51] & $\begin{array}{l}\text { the low temperature sintered of } \\
\qquad \text { NiCuZn ferrites }\end{array}$ & $\begin{array}{l}\text { For higher Cu content initial } \\
\text { permeability increases continuously } \\
\text { with temperature. }\end{array}$ \\
\hline 12. & Roy and Bera & {$[55]$} & $\begin{array}{l}\text { The effect of } \mathrm{Mg} \text { substitution on } \\
\text { electromagnetic properties of } \\
\left(\mathrm{Ni}_{0.25-x} \mathrm{Mg}_{\mathrm{x}} \mathrm{Cu}_{0.2} \mathrm{Zn}_{0.55}\right) \mathrm{Fe}_{2} \mathrm{O}_{4}\end{array}$ & $\begin{array}{l}\text { The permeability were found to } \\
\text { increase and the magnetic loss } \\
\text { decreased with } \mathrm{Mg} \text { substitution for } \\
\mathrm{Ni} \text {, }\end{array}$ \\
\hline 13. & Zhang et.al., & [59] & $\begin{array}{l}\text { The investigation on structure and } \\
\text { properties of low temperature } \\
\text { sintered composite ferrites: viz., } \\
\left(\mathrm{Ni}_{0.60} \mathrm{Zn}_{0.20} \mathrm{Cu}_{0.20}\right) \mathrm{Fe}_{2} \mathrm{O}_{4} \text { spinel ferrite } \\
\text { powder and } \mathrm{Co}_{2} \mathrm{Z} \text { were synthesized } \\
\text { by self propagating method. }\end{array}$ & $\begin{array}{c}\text { The composite ferrites have } \\
\text { excellent electromagnetic } \\
\text { properties in hyper frequencies } \\
\text { more than } 1.5 \mathrm{GHz} \text {. }\end{array}$ \\
\hline
\end{tabular}




\begin{tabular}{|c|c|c|c|c|}
\hline S.No & Author Name & Ref. No. & Studies Carried Out & Observations/Conclusions \\
\hline \multicolumn{5}{|c|}{ Initial Permeability Studies } \\
\hline 14. & Qi et.al., & {$[60]$} & $\begin{array}{l}\text { the magnetic properties of composite } \\
\text { materials with a ferrimagnetic } \\
\mathrm{Ni}_{0.2} \mathrm{Cu}_{0.2} \mathrm{Zn}_{0.6} \mathrm{Fe}_{1.96} \mathrm{O}_{4} \text { phase and a } \\
\text { ferro electric } \mathrm{BaTiO}_{3} \text { phase }\end{array}$ & $\begin{array}{l}\text { The saturation magnetization and } \\
\text { initial permeability decreases with } \\
\text { increasing ferroelectric content } \\
\mathrm{BaTiO}_{3} \text { phase. }\end{array}$ \\
\hline 15. & Wu et.al., & {$[70]$} & $\begin{array}{l}\text { the preparation of NiZn ferrites } / \mathrm{SiO}_{2} \\
\text { nano composite powders by sol-gel } \\
\text { auto combustion method. }\end{array}$ & \\
\hline 16. & Su et.al., & [79] & $\begin{array}{l}\text { Effects of composition and sintering } \\
\text { temperature on grain size, porosity } \\
\text { and magnetic properties of the NiZn } \\
\text { and NiCuZn ferrites }\end{array}$ & $\begin{array}{l}\text { The lowest power loss could be } \\
\text { obtained with the equimolar } \\
\text { composition for both NiZn and } \\
\text { NiCuZn ferrites, which was } \\
\text { attributed to the lowest porosity in } \\
\text { those samples. }\end{array}$ \\
\hline \multicolumn{5}{|c|}{ Stress Insensitivity Studies } \\
\hline 17. & $\begin{array}{l}\text { Ramamanohar } \\
\text { Reddy et.al., }\end{array}$ & [19] & $\begin{array}{l}\text { Stress sensitivity of inductance in } \\
\qquad \text { NiCuZn ferrites }\end{array}$ & $\begin{array}{l}\text { Stress sensitivity is more in the case } \\
\text { of iron rich and stoichiometric iron } \\
\text { samples while in the case of iron } \\
\text { deficient samples the stress } \\
\text { sensitivity was found to be less. }\end{array}$ \\
\hline 18. & Kanada et.al., & [27] & $\begin{array}{l}\text { The effects of chemical composition } \\
\text { and micro structure on stress } \\
\text { sensitivity of magnetic properties to } \\
\text { applied stress of Ni-Mg-Cu-Zn ferrite } \\
\text { materials }\end{array}$ & $\begin{array}{l}\text { They found that the application of } \\
\text { external stress reduces the } \\
\text { permeability. }\end{array}$ \\
\hline 19. & Kanada et.al., & [36] & $\begin{array}{l}\text { The effects of chemical composition } \\
\text { and micro structure on stress } \\
\text { sensitivity of magnetic properties } \\
\text { with applied stress in Ni-Mg-Cu-Zn } \\
\text { ferrite materials were investigated, }\end{array}$ & $\begin{array}{l}\text { On application of stress sensitivity } \\
\text { was reduced. }\end{array}$ \\
\hline 20. & Ikeda and Kumagi & [48] & $\begin{array}{l}\text { Developments of stress-insensitive } \\
\text { ferrite }\end{array}$ & $\begin{array}{l}\text { The sensitivity of the magnetic } \\
\text { property to the external stress in } \\
\text { NiCuZn ferrite was examined from } \\
\text { the relationship between stress and } \\
\text { permeability. }\end{array}$ \\
\hline 21. & Nakano et.al., & [49] & $\begin{array}{l}\text { Development of low temperature } \\
\text { fired NiCuZn ferrites and studied the } \\
\text { high performance multilayer chip } \\
\text { inductors }\end{array}$ & $\begin{array}{l}\text { Controlling stress by the internal } \mathrm{Ag} \\
\text { conductor and } \mathrm{CuO}_{1-\mathrm{x}} / \mathrm{Ag} \text { on ferrites } \\
\text { grain boundary is most important } \\
\text { key point for high performance } \\
\text { multilayer chip ferrites as well as the } \\
\text { chemical composition of ferrite }\end{array}$ \\
\hline 22. & Nakano et.al., & [51] & $\begin{array}{l}\text { The magnetic properties of } \mathrm{Mg}-\mathrm{Cu}-\mathrm{Zn} \\
\text { ferrites under stress were investigated } \\
\text { and compared with } \mathrm{Ni}-\mathrm{Cu}-\mathrm{Zn} \text { ferrite } \\
\text { under a compressive stress. }\end{array}$ & $\begin{array}{l}\text { The change in permeability with } \\
\text { stress of low temperature sintered } \\
\text { MgCuZn ferrite was lower than that } \\
\text { of low temperature sintered NiCuZn } \\
\text { ferrite. }\end{array}$ \\
\hline
\end{tabular}




\begin{tabular}{|c|c|c|c|c|}
\hline S.No & Author Name & Ref. No. & Studies Carried Out & Observations/Conclusions \\
\hline \multicolumn{5}{|c|}{ Initial Permeability Studies } \\
\hline 23. & Aoki et.al., & {$[52]$} & $\begin{array}{l}\text { The effect of } \mathrm{SiO}_{2} \text { on the bending } \\
\text { strength of } \mathrm{NiCuZn} \text { ferrite }\end{array}$ & $\begin{array}{l}\text { The bending strength of NiCuZn } \\
\text { ferrite was increased by the addition } \\
\qquad{\text { of } \mathrm{SiO}_{2} .} .\end{array}$ \\
\hline 24. & Aoki et.al., & [57] & $\begin{array}{l}\text { The studies on the bending strength } \\
\text { of sintered MgCuZn, NiCuZn, and } \\
\text { MnZn ferrites. }\end{array}$ & $\begin{array}{l}\text { The much residual carbon content } \\
\text { affects the bending strength of } \\
\text { these sintered ferrites. }\end{array}$ \\
\hline 25. & Nakano et.al., & [59] & $\begin{array}{l}\text { The development of low temperature } \\
\text { NiCuZn ferrites and study of high } \\
\text { performance for multilayer chip } \\
\text { ferrites }\end{array}$ & $\begin{array}{l}\text { The controlling stress by the internal } \\
\text { Ag-conductor and } \mathrm{CuO}_{1-x} / \mathrm{Ag} \text { on } \\
\text { ferrites grain boundary is most } \\
\text { important for high performance } \\
\text { multilayer chip ferrites as well as the } \\
\text { chemical composition of ferrite. }\end{array}$ \\
\hline 26 & Our Result & ----- & $\begin{array}{l}\text { High permeability and Stress } \\
\text { insensitivity of MgCuZn -NiCuZn } \\
\text { ferrite composites for microinductor } \\
\text { applications }\end{array}$ & $\begin{array}{l}\text { Equimolar mixture of the ferrite } \\
\text { composites showed high initial } \\
\text { permeability }\left(\mu_{\mathrm{i}}\right) \text { of the order of } \\
\text { 9619. It may be pointed out that } \\
\text { this composition is fairly stress } \\
\text { independent also. } \\
\text { Not only equimolar composition, } \\
\text { even the } \mathrm{Mg}_{0.25} \mathrm{Cu}_{0.25} \mathrm{Zn}_{0.5} \mathrm{Fe}_{2} \mathrm{O}_{4} \text { also } \\
\text { showed stress insensitivity. }\end{array}$ \\
\hline
\end{tabular}

\section{Acknowledgements}

This work was financially supported by Defence Research and Development Organization (DRDO), under the grants ERIP/ER/0103301/M/01, New Delhi, India. The authors are thankful to the authorities of Sri Krishnadevaraya University, Anantapur for providing the facilities.

\section{Author details}

N. Varalaxmi ${ }^{1,2}$ and K. Sivakumar ${ }^{2}$

*Address all correspondence to: narlasharma55@gmail.com

1 Department of Physics, Kakatiya University,Warangal, India

2 Ceramic Composite Materials Laboratory, Department of Physics, Sri Krishnadevaraya University, S.V. Puram, Anantapur, India 


\section{References}

[1] T. Nomura and M. Takaya. Hybrids., 3 (1987) pp.15.

[2] A. Ono, T. Muruno and N. Kaihara. Jpn. Elec. Engg., 28 (1991) pp.5.

[3] T. Nomura and A. Namano. "Proc of $6^{\text {th }}$ International Conference on Ferrites" Kyoto: Japan Soc.of Powd and Powd .Metall., (1992) pp.1198.

[4] A. Nakano, H. Momoi and T.Nomura. "Proc of $6^{\text {th }}$ International Conference on Ferrites" Kyoto: Japan Soc.of Powd and Powd. Metall., (1992) pp.1225.

[5] T. Nakamura.J. Magn. Magn. Mater., 168 (1997) pp.285.

[6] J. G. Koh and C. I. Yu.New Phys., (Korean Phys, Soc.) 24 (1984) pp.359.

[7] D. N. Bhosale, N. D. Choudhari, S. R. Swant and P. P. Bakare. J. Magn. Magn. Mater., 173 (1997). pp.51.

[8] J. Park, J. Kim and S. Cho J. Phys., (France) C1-193 (1997) pp.7.

[9] J. G. Koh and K. U. Kim. New Phys., (Korean. Phys. Soc.,) 26 (1986) pp.540.

[10] X. Qi, J. Zhou, Z.Yue, et.al., Key. Eng. Mater., 224-226 (2002) pp.593.

[11] H. Zhang, Z. Ma, J. Zhou, Z. Yue, L. Li and Z. Gui. J. Magn. Magn. Mater., 213 (2000) pp.304.

[12] X. Qi, J. Zhou, Z.Yue, Z. Gui and L. Li. J. Magn. Magn. Mater., 251 (2002) pp.316.

[13] A. Nakano, I. Nakahata and T. Murase. J. Jpn. Soc. Powd and Powd Metall., 48 (2001) pp.131.

[14] N. Rezlescu, E. Rezlescu, P. D. Popa, L. Craus and L. Rezlescu. J. Magn. Magn. Mater., 182 (1998) pp.199.

[15] N. Rezlescu, L. Sachlarie, E. Rezlescu and P. D. Popa Cryst Res. Technl., 36 (2001) pp. 157.

[16] L. Sachlarie, E. Rezlescu and N. Rezlescu.Phys. Stat. Solidi., (a) R1 (2000) pp.179

[17] R. D. Waldran. Phys.Rev., 99 (1955) pp.1727.

[18] S. S. Bellad, R. B. Pujar and B .K. Chougle. Ind. J. Pure Appl. Phys., [In press]

[19] A. Nakano, T. Suzuki and H. Momoi .J. Japan. Soc. Powd and Powd. Metall., 49 (2002) pp.77.

[20] I. Kanada, T. Aoki, T. Murase and T. Nomura. J. Japan. Soc. Powder and Powd. Metall., 46 (1999) pp.636.

[21] M. Yan, J. Hu, W. Lu and W. Zhang J. Magn. Magn. Mater., 303 (2006) pp.249.

[22] O. F. Caultn, L. Spinu and A. Stancu IEEE. Trans. Magn., 37 (2001) pp.2353. 
[23] T. Nakamura, T. Sutaoka and K. Hatakeyama. J. Magn. Magn. Mater., 13 (1994) pp. 319.

[24] J. H. Oh. IEEE Trans. Magn., 35 (1999) pp.3412.

[25] H. Su, H. Zhang, X. Tang, Y. Jing, and Y. Liu. Mater. Letts., 61 (2007) pp.256.

[26] S. Murayama, S. Kumagi and Y. Ikeda. "Proc of $6^{\text {th }}$ International Conference on Ferrites" Kyoto, Japan (1992) pp.366.

[27] I. Kanada, T. Murase and T. Nomura. J. Japan. Soc. Powd and Powd Metall.,48 (2001) pp.136.

[28] D. N. Bhosale,, S. R. Sawant Mater. S. A. Gangal, R. R. Mahajan and P. P. Bakare. Letts., 41 (1999) pp.247.

[29] M. Yan and J. Hu. J. Magn. Magn. Mater., 305 (2006) pp.171.

[30] S. A. Ghodake U. R. Ghodake, S. R. Sawant, S. S. Suryavanshi and P. P. Bakare. J. Solid. State. Chem., 179 (2006) pp.1892.

[31] X. Y. Gao, Y. Cao, Y. Zhou, W. Ding, C. Lei and J.A. Chen J. Magn. Magn. Mater., 305 (2006) pp.207.

[32] D. N. Bhosale, S. R. Sawant S. A. Gangal, R. R. Mahajan and P. P. Bakare. Mater. Sci and Engg., B65 (1999) pp.79.

[33] S. F. Wang, Y. R. Wang, C. K. Thomas Yang, C. F. Chen, C. A. Lu and C. Y. Huang. J. Magn. Magn. Mater., 220 (2000) pp.129.

[34] H. Su, H. Zhang and X. Tang. J. Magn. Mater. Devices., 3 (2004).pp.13.

[35] D. Mukesh, A. Verma, Subash C. Kashyap, D. C. Dube, Subash C. Kashyap, D. C. Dube, O. P. Thakur and Chandraprakash. Mater. Sci and Engg., B13 (2006) pp.42.

[36] A. Oi, A. Nakano and T. Nomura.J. Japan. Soc. Powd and Powd Metall., 47 (2000), pp.779.

[37] I. Nakahata, T. Murase. and A. Nakano. J. Japan. Soc. Powd and Powd and Metall., 48 (2001) pp.126.

[38] N. Ramamanohar Reddy, M. VenkataRamana, G. Rajitha, E. Rajagopal, K. V. SivaKumar, and V. R. K. Murthy. J. Magn. Magn. Mater., 292 (2005) pp.159.

[39] J. H. Nam, H. H. Jung, J. Y. Shin and J. H. Oh. IEEE Trans. Magn., 31 (1995) pp.3985.

[40] O. F. Caultn, L. Spinu, Al. Stancu, L. D. Thung and W. Zhou.J. Magn. Magn. Mater., 242-245 (2002) pp.160.

[41] S .F. Wang, Y. R. Wang, C. K. Thomas Yang, P. J. Wang and C. A. Lu. J. Magn. Magn. Mater., 217 (2000) pp.35.

[42] S. F. Wang, Y. R. Wang, C. K. Thomas Yang, C.F Chen C. A. Lu and C.Y.Huang.J. Magn. Magn. Mater., 22 (2000) pp.129. 
[43] S. Ramana Murthy. Bull. Mater. Sci., 24 (2001) pp.379.

[44] S .F. Wang, Y. R. Wang, C. K. Thomas Yang, C.F Chen and C.A. Lu. Scripta Mater., 43 (2000) pp.269.

[45] D. N. Bhosale, N. D. Choudhari, S. R. Sawant, D.K. Rajendra,and P.P.Bakare. IEEE.Trans. Magn., 34 (1998) pp.535.

[46] W. C. Kim, S .L. Park, S. J. Kim S. W. Lee and C. S. Kim. J. Appl. Phys., 87 (2000) pp. 6241.

[47] H. Su, H. Zhang, X. Tang, I. Y. Jing and Y. Liu. J. Magn. Magn. Mater., 310 (2007) pp. 17.

[48] D. N. Bhosale, N. D. Choudhari, S. R. Sawant and P. P. Bakare J. Magn. Magn. Mater., 173 (1997) pp.1.

[49] Z. Yue, J. Zhou, L. Li, X. Hui and Z. Gui. Mater. Sci and Engg., B86 (2001) pp.64.

[50] Z. Yue, J. Zhou, L. Li, and Z. Gui. J. Magn. Magn. Mater., 233 (2001) pp.224.

[51] S. RamanaMurthy. J. Mater. Sci.Letts., 21 (2002) pp.657.

[52] X. Qi, J. Zhou, Z. Yue, Z. Gui and L. Li. J. Magn. Magn. Mater., 251 (2002) pp.316.

[53] A. Bhaskar, B. Rajini Kanth, and S. Ramana Murthy, J. Mater. Sci., 39 (2004) pp.3787.

[54] L. M. Hyie , I.H.S.C. Metselaar and I. I. Yaacob. Key. Engg. Mater., 306- 308 (2006) pp. 875.

[55] P. K. Roy and J. Bera J. Magn. Magn. Mater., 298 Issue 1, (2006) pp.38.

[56] Kin O. Low and Frank R. Sale. J. Magn. Magn. Mater., 256 (2003) pp.221.

[57] E. Rezlescu, N. Rezlescu, P. D. Popa, L. Rezlescu, C. Pasnicu and M. L. Craus. Bull .Mater. Res., 33 (1998) pp.915.

[58] K. S. Park, J. H. Nam and H. Lee. J. Magn. Soc.of .Japan., 22 and J. Suppl, No.S1 (1998).

[59] H. Zhang, L. Li, P. Wu, J. Zhou, Z. Ma and Z. Gui. Bull. Mater. Res., 35 (2000) pp. 2207.

[60] X. Qi, J. Zhou, Z. Yue, Z. Gui and L. Li. J. Magn. Magn. Mater., 269 (2004) pp.352.

[61] T. Aoki. T. Murase and T. Nomura. J. Japan. Soc. Powd and Powd Metall., 48 (2001) pp.140.

[62] A. Nakano and T. Nomura. "Proc of $8^{\text {th }}$ International Conference on Ferrites"Kyoto, Japan. (2000) pp.1117.

[63] K. Amarendra Singh, T.C. Goel and G. Mendiratta. Jpn. J. Appl. Phys., 42 (2003) pp. 2690. 
[64] T. T. Srinivasan, P. Ravindranathan, L. E. Cross, R. Roy , R. E. Newnham, S. G. Sankar, and K. C. Patil. J. Appl. Phys., 6315 (1988) pp.3789.

[65] D. Y. Ju and P. Bian. "Transactions of Nonferrous Metals Society of China" (English Edition) 16 (Suppl.) (2006) pp. s67.

[66] H. Zhang, Z. Ma, J. Zhou, Z. Yue, L. Li and Z. Gui.J. Magn. Magn. Mater., 213 (2000) pp.304.

[67] C. S. Kim, W.C. Kim, S.Y.An, and S.W.Lee.J. Magn. Magn. Mater., 215 - 216 (2000) pp. 213.

[68] C. Y. Tsay, K. S. Liu, T. F. Lin, and I. N. Lin. J. Magn. Magn. Mater., 209 (2000) pp.189.

[69] S. F. Wang, Y. R. Wang, C. K.Thomas, C. F. Chen and C. A. Lu. Scripta Mater., 43 (2000) pp.269.

[70] K. H. Wu, Y.C. Chang and G. P. Wang. J. Magn. Magn . Mater., 269 (2004) pp.150.

[71] B. O. Ladgaonkar "National DAE-BRNS Symposiumon Recent Trends in Electro and Magnetoceramics" Shivaji University, Kolhapur, India. (1999).

[72] D. N. Bhosale, N. D. Choudhari, S. R. Sawant and P. P. Bakare. J. Magn. Magn. Mater., 173 (1997) pp.51.

[73] U. R. Ghodake, S. A. Ghodake, J. S. Ghodake, S. L. Darshane, P. P. Bakare, S. R. Sawant and S. S. Suryavanshi. "Materials for Advance Technologies.: Proc. NASMAT- Shivaji University, Kolhapur, India (2006).

[74] S. S. Suryavanshi, S .R. Sawant, R. S. Patil and S.A. Patil. Ind. J. Pure and Appl. Phys., 29 (1991) pp.644.

[75] H. Umeda, I. Kanada, T. Murase and T. Nomura. J. Japan. Soc. Powd and Powd. Metall., 47 (2000) pp.774.

[76] T. Krishnaveni, S. Komarneni, and S. R. Murthy. "Synthesis and Reactivity in InorganicMetal-Organic and Nano-Metal Chemistry"., 36 (2006) pp.143.

[77] B. P. Ladgaonkar, P. P. Bakare, S. R. Sainkar and A. S. Vaingankar. Mater. Chem and Phys., 69 (2001) pp.19.

[78] Yomen Attasi and Mohamed Tally. Physics Abstract, 0602129, (2006).

[79] H. Su, H. Zhang, X. Tang, Y. Jing and Y. Liu. Mater. Letts., 6 (2007) pp.256.

[80] D. N.Bhosale, S. R. Sawant, S. A. Gangal, R. R. Mahajan, and P. P. Bakare. Mater. Sci. Engg., B6 (1999) pp.79

[81] Souliah Zahi, Mansor Hashim and A.R.Daud.J. Magn. Magn. Mater., 30 (2007) pp.177.

[82] S. A. Ghodake, U. R. Ghodake, S. R. Sawant, S. S. Suryavanshi, J. Magn. Magn. Mater., 305 (2006) pp.110.

[83] J. Hu, M. Yan and W.Y. Zhang. Mater. Chem and Phys., 98 (2006) pp.459. 
[84] T. Y. Byun, S.C. Bycon and K. S. Hong. IEEE Trans. Magn., 35 (1999) pp.3445.

[85] Z.Yue, J.Zhou, Z.Gui and L.Li. J. Magn. Magn. Mater., 264 (2003) pp.258.

[86] J. Hu and M.Yan. J. Zhejiang Univ Sci 6B (6) (2005) pp.580.

[87] T. Krishnaveni, S. R. Murthy, F. Gao, Q. Lu and S. Komarneni. J. Mater. Sci., 41 (2006) pp.1471.

[88] A. Bhaskar, B. R. Kanth, and S. R. Murthy. J. Magn. Magn. Mater., 28 (2004) pp.109.

[89] T.Murase, T. Akoi and H. Umeda.J.Japn. Soc. Powd and Powd Metall., 52 (2005) pp.199.

[90] T. Krishnaveni and S. R. Murthy. Proc. of SPIE., 5650 (2005) pp.285.

[91] C. D. Mukesh, C. Subhash, D. Kashyap, C. Dube and S. K. Mohanta. J. Electro. Ceram 16 (2006) pp.331.

[92] H. Su, H. Zhang, X.Tang L. Jia and Q. Wen. Mater. Sci. Engg., B 129 (2006) pp.172.

[93] H. Su, H. Zhang, X.Tang and X. Xiang. J. Magn. Magn. Mater., 383 (2004) pp.157.

[94] X. Wang, W. Qu, L. Li and Z. Gui. Ceram. Intern., 30 (2004) pp.1615.

[95] B. Li , Z. Yue, X. Qi, J. Zhou, Z.Gui and L.Li. Mater. Sci. Engg., B99 (2003) pp.252.

[96] X. Y. Gao, Y. Cao, Y. Zhou, W. Ding, C. Li and J. A. Chen. J. Magn. Magn. Mater., 305 (2006) pp.207.

[97] Su-il Pyun and Jong-Tae Baek. J. Amer. Ceram. Soc. Bull., 6 (1985) pp.602.

[98] Zbigniew Kaczkowski. J. Magn. Magn. Mater., 41 (1984) pp.338.

[99] M. I. Abd.El-Ati and A. Tawafik. J. Ther. Anal and Calor., 37 (1991) pp.2465.

[100] Y. Enokido, H. Saitah, N. Sato,v "Advances in Science Technology, World Ceramics Congress", Florence,ITALIE (14-19 June 1998).

[101] T. Yamaguchi and M. Shingawa. J. Mater. Sci., 30 (1995) pp.504.

[102] Y. Ikeda and M. Kumagi. J. Japan. Soc. Powd and Powd Metall., 48 (2001) pp.2465.

[103] M. Kumagi and Y. Ikeda. "Proc of $5^{\text {th }}$ International Conference on Ferrites"., Bombay, India (1989) pp.625.

[104] A. Nakano. I. Nakahata J. Japan. Soc. Powd and Powd Metall., 48 (2001) pp.131.

[105] T. Akoi, H. Umeda, K. Akasura and T. Musare.J. Japan. Soc. Powd and Powd Metall., 53 (2006) pp.273.

[106] T.Akoi, T.Musare and T. Nomura J.Japan. Soc. Powd and Powd Metall., 53 (2006) pp.273.

[107] M. Fujimoto J. Am. Ceram. Soc., 77 (1994) pp.2873.

[108] J. Smit and H .P. J. Wijn. "Ferrites"., Philips Technical Library Eindhoven, Nether lands, (1959). 